\title{
Autonomic regulation of islet hormone secretion - Implications for health and disease
}

\author{
B. Ahrén \\ Department of Medicine, Lund University, Malmö, Sweden
}

\section{Abstract}

The pancreatic islets are richly innervated by parasympathetic, sympathetic and sensory nerves. Several different neurotransmitters are stored within the terminals of these nerves, both the classical neurotransmitters, acetylcholine and noradrenaline, and several neuropeptides. The neuropeptides, vasoactive intestinal polypeptide, pituitary adenlyate cyclase activating polypeptide and gastrin releasing peptide are constituents of the parasympathetic nerves, whereas the neuropeptides galanin and neuropeptide Y are localised to sympathetic nerve terminals. Furthermore, the neuropeptide calcitonin gene-related peptide is localised to sensory nerves and cholecystokinin is also an islet neuropeptide, although the nature of the cholecystokinin nerves is not established. Stimulation of the autonomic nerves and treatment with neurotransmitters affect islet hormone secretion. Thus, insulin secretion is stimulated by parasympathetic nerves or their neurotransmitters and inhibited by sympathetic nerves or their neurotransmitters. The islet autonomic nerves seem to be of physiological im- portance in mediating the cephalic phase of insulin secretion, in synchronising the islets to function as a unit allowing oscillations of islet hormone secretion, and in optimising islet hormone secretion during metabolic stress, e.g. hypoglycaemia and neuroglycopenia. The autonomic nerves could also be involved in the islet adaptation to insulin resistance with possible implication for the development of glucose intolerance and Type II (non-insulin-dependent) diabetes mellitus. It is concluded that islet innervation, through the contribution of all branches of the autonomic nerves and several different neurotransmitters is of importance both for the physiology and pathophysiology of the islets. [Diabetologia (2000) 43:393-410]

Keywords Islets, parasympathetic, sympathetic, acetylcholine, vasoactive intestinal polypeptide, pituitary adenylate cyclase activating polypeptide, gastrin releasing peptide, noradrenaline, galanin, neuropeptide Y, calcitonin gene-related polypeptide, cholecystokinin, insulin secretion, glucagon secretion, cephalic phase, oscillation, hypoglycaemia, impaired glucose tolerance, diabetes.
Corresponding author: B. Ahrén, MD, PhD, Department of Medicine, Malmö University Hospital, S-205 02 Malmö, Sweden

Abbreviations: AA, Arachidonic acid; CCK, cholecystokinin; CGRP, calcitonin gene-related polypeptide; CRLR, calcitonin receptor like receptor; DAG, diacyl glycerol; 2-DG, 2-deoxy glucose; GRP, gastrin releasing polypeptide; IAPP, islet amyloid polypeptide; NPY, neuropeptide Y; PACAP, pituitary adenylate cyclase activating polypeptide; PI, phosphoinositides; PKC, protein kinase C; PLA 2 , phospholipase $\mathrm{A}_{2}$; PLC, phospholipase C; PLD, phospholipase D; PP, pancreatic polypeptide; RAMP, receptor activity modifying proteins; SP, substance P; VIP, vasoactive intestinal polypeptide.
Our knowledge of autonomic regulation of islet function begins with the observation by Paul Langerhans that pale, non-myelinated nerve fibres exist in the rabbit and cat pancreas. These nerve fibres were shown tube connected to intrapancreatic ganglia and form a rich neural plexus joining the specific cellular system, later named the islets of Langerhans [1]. In the early $1900 \mathrm{~s}$, numerous light microscopy studies confirmed that there is nervous supply to the islets in a variety of different species including humans [2]. During the 1960 s, studies using electron microscopy showed nerve terminals in a synaptic-like manner in 


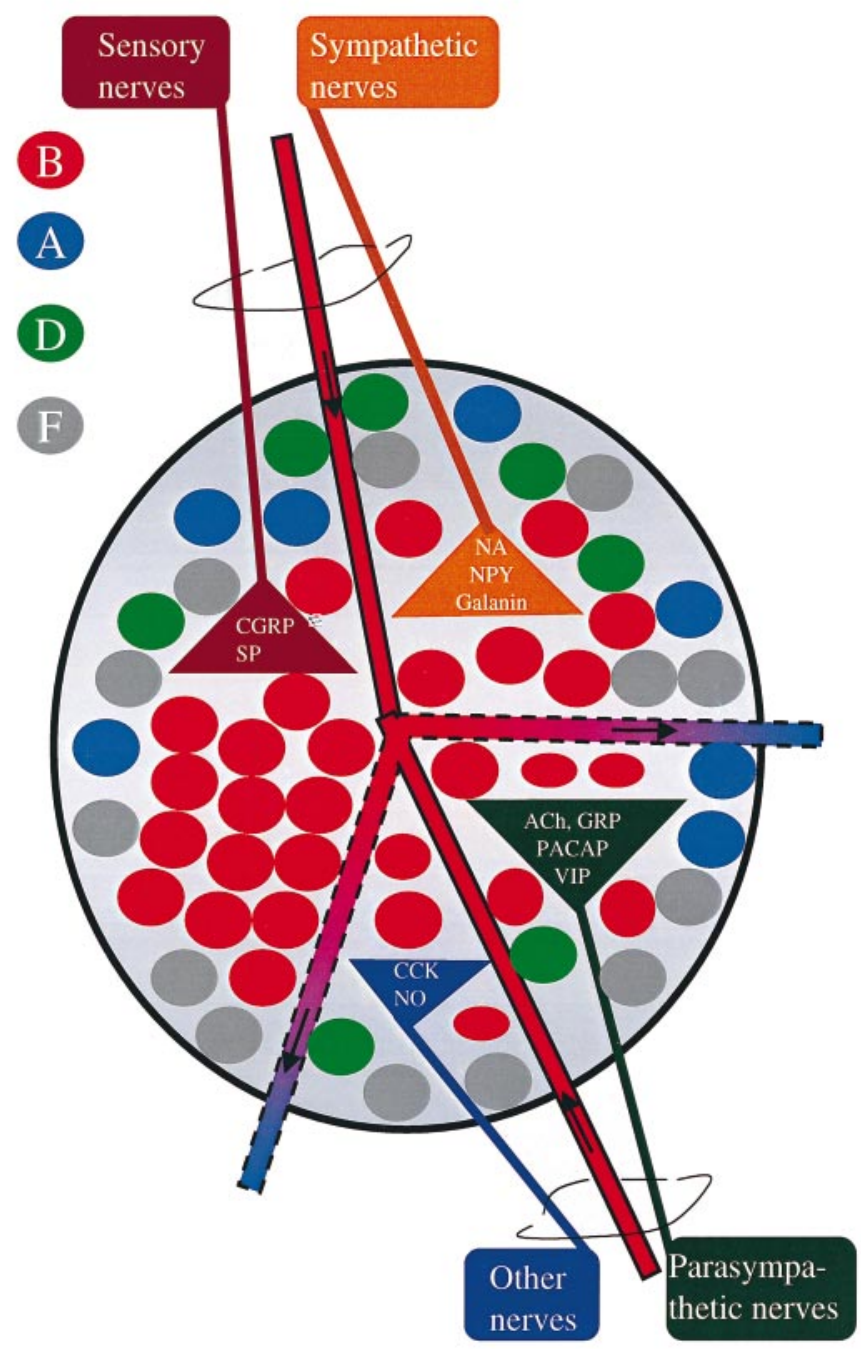

Fig. 1. Schematic view of the innervation of a pancreatic islet with the main branches of the autonomic nerves (parasympathetic nerves, sympathetic nerves, sensory nerves and other nerves) with their respective neurotransmitters. The four main types of islet endocrine cells are also illustrated with beta cells (B) forming the central islet portion, whereas an islet mantle zone harbours alpha cells (A cells, glucagon cells), delta cells ( $\mathrm{D}$ cells, somatostatin cells) and F cells (pancreatic polypeptide (PP) cells). Afferent vessels (red) and fenestrated efferent vessels (red to blue) are also illustrated (arrows indicate blood flow direction). $\mathrm{ACh}=$ acetylcholine, $\mathrm{NO}=$ nitric oxide

close proximity to all four major types of islet endocrine cells. Sometimes more than three nerve terminals were found to approach a single endocrine cell $[3,4]$. The nature of these islet nerves was studied using histochemical and fluorescene staining techniques during the $1950 \mathrm{~s}$ and $1960 \mathrm{~s}$. These techniques revealed localisation of cholinesterase to some of the islet nerves and catecholamines to other nerves, indicating that both cholinergic and adrenergic nerves innervate the islets $[5,6]$. In general, the nerve fibres enter the islets along the vessels and form either a peri-insular network in the mantle zone of the islet or pass directly to an islet endocrine cell. During the 1960 s, 1970 s and 1980 s, numerous functional studies showed changes in islet hormone secretion both after electrical activation of the autonomic nerves and by challenge with adrenergic and cholinergic agonists and antagonists in a variety of experimental conditions $[2,7,8]$. In the last two decades, it has also become apparent that apart from the classical neurotransmitters, several neuropeptides are also localised to islet nerve terminals. Because these neuropeptides also affect islet function it has become apparent that neuropeptidergic nerves are involved in the neuroregulation of islet function as well [7, 9]. Figure 1 illustrates the neural relation to an islet with emphases on the neurotransmitters involved. Finally, during recent years information has emerged suggesting islet autonomic nerves are involved in physiological and pathophysiological processes. In this article, our current knowledge of the role of autonomic regulation of islet function is reviewed, focusing on aspects of physiological and clinical importance.

\section{Parasympathetic nerves}

Anatomy. The cholinergic nerve fibres innervating the islets are of postganglionic origin and emanate from the intrapancreatic ganglia [7, 8]. These ganglia are controlled by the preganglionic fibres, originating primarily in the dorsal motor nucleus of the vagus [7, $8,10]$. The preganglionic fibres traverse the vagus, mainly as part of the bulbar outflow tract [8] and the hepatic and gastric branches of the vagus [10]. They enter the pancreas along the vessels and terminate at intrapancreatic ganglia, from which the postganglionic nerves pass to the islets; these nerves penetrate the islets to terminate close to the endocrine cells [7-9]. That parasympathetic nerves innervate the islets has been verified in a number of species by light and electron microscopy after staining pancreatic sections with cholinesterase $[3,5,7,8]$. The relative abundance of the islet cholinergic innervation is evident because isolated islet tissue has a tenfold higher concentration of choline acetyltransferase than pancreatic tissue as a whole [11].

Effects. Already during the 1920 s and 1930 s it was hypothesised that vagal activation stimulates insulin secretion because electrical stimulation of the vagus nerve was found to lower blood glucose in both cats and dogs [2]. This hypothesis was verified after the introduction of radioimmunoassay techniques in the $1960 \mathrm{~s}$, when it became possible to measure islet hormones. Electrical activation of the vagus nerve was shown to stimulate insulin secretion both in vivo and in vitro in several different species including humans $[7,8,10,12-14]$. Extrapancreatic stimulation of the 
vagus nerve releases acetylcholine from the preganglionic terminals in the ganglia which activates nicotinic receptors on the nerve cell bodies of the postganglionic nerves. This implies a nicotonic mechanism mediates vagally induced insulin secretion. Verification came from findings that nicotinic blockade by hexamethonium abolishes the insulin secretory response to vagal nerve activation [14] and specific pharmacologic nicotinic activation in adrenalectomised animals (to exclude any action through a nicotinic-induced release of adrenaline) in vivo stimulates insulin secretion [15]. As has, however, been shown in the perfused canine pancreas, ganglionic transmission could be more complex than simply involving nicotinic mechanisms. Possibly several other transmission pathways are also involved [16], but this has not been explored in great detail.

The postganglionic nerve fibres innervating the islets release acetylcholine, which directly stimulates insulin secretion from the islet beta cells through activation of muscarinic receptors. The muscarinic nature of the action has been verified by immunocytochemistry showing localisation of muscarinic receptors in the islets with a higher density than in surrounding pancreatic tissue [17] and the detection of cDNAs encoding for muscarinic receptors in islet tissue [18]. Furthermore, numerous studies have found that exogenous treatment with acetylcholine or other muscarinic agonists stimulates insulin secretion in vivo and in vitro in several species by an effect which is inhibited by muscarinic antagonism by atropine [2, $7,8,19]$. It has also been established that vagal nerve activation stimulates the secretion of the other three islet hormones, glucagon, somatostatin and pancreatic polypeptide (PP) $[12,13,20]$. The secretions of glucagon and somatostatin are likewise stimulated by pharmacological cholinergic agonism (acetylcholine or carbachol) [20-22]. It seems therefore to be established that the parasympathetic nervous system affects secretion of islet hormones by a general stimulatory action. The potent stimulation of PP secretion is of particular interest because the plasma concentration of PP is frequently used as an indirect marker for parasympathetic activity [23].

Islet muscarinic receptor subtype. At present five different muscarinic receptors (m receptors) have been discovered with subtype specific characteristics for gene encoding, cellular expression and signalling mechanisms [24]. Several pharmacological studies have been undertaken to establish which muscarinic receptor subtype is important for insulin secretion. An $\mathrm{m} 3$ receptor antagonist was found to inhibit cholinergically induced insulin secretion and bind more efficiently to isolated rat islets than $\mathrm{m} 1$ or $\mathrm{m} 2$ receptor antagonists [25]. Furthermore, in isolated mouse islets, antagonists to $\mathrm{m} 1$ and $\mathrm{m} 2$ receptors have no effect on cholinergically induced insulin secretion [26].
Moreover, in vivo in mice, $\mathrm{m} 3$ receptor antagonist inhibits cholinergically induced islet hormone secretion more efficiently than inhibitors of the $\mathrm{m} 1$ and $\mathrm{m} 2$ receptor subtypes [22]. Glucagon secretion, like insulin secretion, is also stimulated by activation of the $\mathrm{m} 3$ receptor subtype $[22,25]$. Therefore, the indications so far are that the $\mathrm{m} 3$ receptor subtype is important for mediating cholinergically induced islet hormone secretion. This is also supported by cDNAs encoding for $\mathrm{m} 3$ receptors in islets [18].

Islet signalling of muscarinic receptor activation. A main characteristic of cholinergic islet effects is a synergistic action with glucose to augment both insulin secretion and phosphoinositide (PI) hydrolysis [27] (Fig.2). Phosphoinositides hydrolysis is stimulated by phospholipase C (PLC) by a mechanism coupled to G-protein. This coupling is initiated by an agonist to binding the muscarinic receptors [28]. Hydrolysis of PI results in formation of $\mathrm{IP}_{3}$, releasing $\mathrm{Ca}^{2+}$ from intracellular $\mathrm{Ca}^{2+}$ stores to raise the cytosolic concentration of $\mathrm{Ca}^{2+}$. Consequently, cholinergic agonism increases the cytosolic concentration of $\mathrm{Ca}^{2+}$ independently from uptake of extracellular $\mathrm{Ca}^{2+}$, which is accompanied by a rapid stimulation of exocytosis and insulin secretion [19, 25, 29]. Because cholinergic agonism activates PLC, diacyl glycerol (DAG) is also formed [30] and because DAG activates protein kinase $\mathrm{C}$ (PKC), insulin secretion induced by carbachol has been shown to be reduced by inhibition of PKC [31]. Moreover, cholinergic agonism also stimulates the generation of arachidonic acid (AA) through activation of $\mathrm{PLA}_{2}[32,33]$. Carbachol has been shown to be even more efficient than glucose in activating $\mathrm{PLA}_{2}$ [32]. The effect activation of PLA $\mathrm{PL}_{2}$ has on insulin secretion, induced by cholinergic agonism, is evident from findings that a PLA $_{2}$ antagonist greatly inhibits exocytosis stimulated by acetylcholine in insulin producing cells [32]. In contrast, carbachol does not seem to increase islet formation of cAMP [19]. The combined action of cholinergic agonists (to release $\mathrm{Ca}^{2+}$ from intracellular stores, to raise the cytosolic concentration of $\mathrm{Ca}^{2+}$, to stimulate the formation of AA and to activate PKC) seems to contribute to the insulinotropic action after activation of the muscarinic receptors. In contrast, the signalling underlying cholinergically induced glucagon secretion is still to be established.

Non-cholinergic mechanisms. Several studies have shown that vagally induced islet hormone secretion is not always sensitive to inhibition by muscarinic antagonism by atropine. In the pig pancreas, for example, vagally induced insulin secretion is resistant to atropine although it is inhibited by hexamethonium [13]. Similarly, in the dog, vagally induced glucagon secretion is resistant to atropine, although atropine reduces more than $80 \%$ of vagally induced insulin se- 


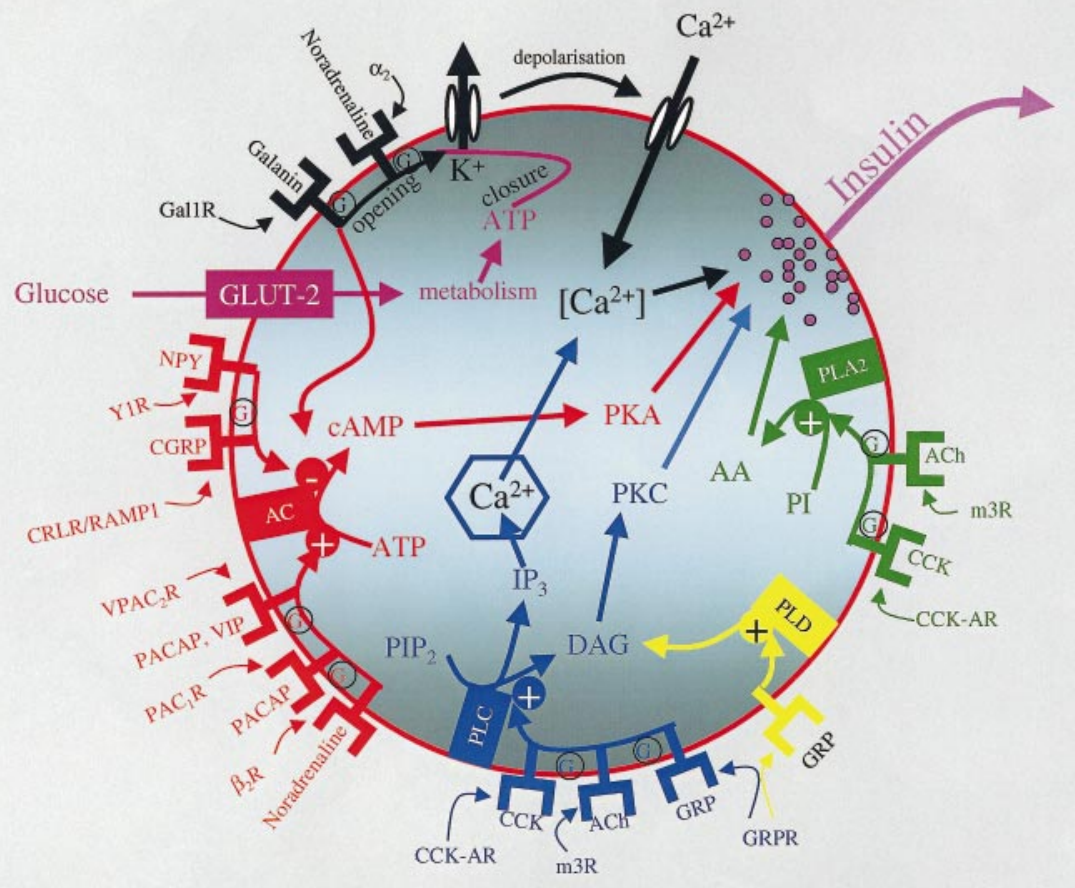

Fig. 2. Schematic view of signalling in the islet insulin producing beta cells with emphases on the pathways activated by receptors which are stimulated by the neurotransmitters from the parasympathetic nerves $(\mathrm{ACh}=$ acetylcholine, $\mathrm{GRP}=$ gastrin releasing polypeptide, $\mathrm{PACAP}=$ pituitary adenylate cyclase activating peptide, VIP = vasoactive intestinal polypeptide), the sympathetic nerves (noradrenaline, galanin and $\mathrm{NPY}=$ neuropeptide $\mathrm{Y})$, the sensory nerves $(\mathrm{CGRP}=$ calcitonin gene-related polypeptide) and other nerves (CCK $=$ cholecystokinin). The main pathways are illustrated in different colours $\left(\mathrm{K}^{+} / \mathrm{Ca}^{+}\right.$channel activity in black, the cAMP (cyclic adenosine monophosphate)-PKA (protein kinase A) pathway in red, the PLC (phospholipase C)-pathway in blue, the PLD (phospholipase D)-pathway in yellow and the PLA 2 (phospholipase $\mathrm{A}_{2}$ )-pathway in green). $\mathrm{AC}=$ adenylate cyclase, $\mathrm{PIP}_{2}=$ phosphatidyl-inositol-biphosphate, $\mathrm{IP}_{3}=$ inositol-1,4,5trisphosphate, $\mathrm{DAG}=$ diacyl glycerol, $\mathrm{AA}=$ arachidonic acid, $\mathrm{PI}=$ phosphoinositides, $\mathrm{PKC}=$ protein kinase $\mathrm{C}, \mathrm{G}=\mathrm{G}$-proteins, CCK-AR = cholecystokinin A receptor, $\mathrm{GalR}=$ galanin receptor, GRPR $=$ GRP receptor, $\mathrm{IP}_{3}=$ inositol trisphosphate, $\mathrm{VIP}=$ vasoactive intestinal polypeptide, $\mathrm{m} 3 \mathrm{R}=$ muscarinic 3 receptor, $\mathrm{PAC}_{1} \mathrm{R}=\mathrm{PACAP}_{1}$ receptor, $\mathrm{VPACR}=\mathrm{VIP} / \mathrm{PACAP}$ receptor. For further explanation see text. It should be emphasised that this illustration is simplified and also that important actions by receptor activation directly on the exocytosis machinery are not indicated. It should also be emphasized that this figure does not indicate that all receptors always are expressed in the same beta cell

cretion in this species [14]. Furthermore, vagally induced somatostatin and PP secretion from the dog pancreas is only partially prevented by atropine [20]. Therefore, although pharmacological cholinergic agonism clearly can stimulate islet hormone secretion through a muscarinic mechanism, non-cholinergic mechanisms also seem to contribute to the action of parasympathetic nerves. This has prompted the search for the non-cholinergic and presumably peptidergic signal(s) which, together with acetylcholine, are responsible for the potent islet hormone secretory response to vagal activation.

Parasympathetic islet neuropeptides. Immunocytochemistry has revealed three neuropeptides in nerve terminals in pancreatic ganglia and in islets in several different species: vasoactive intestinal polypeptide (VIP), gastrin releasing peptide (GRP) and pituitary adenylate cyclase activating polypeptide (PACAP) [7, 9, 34-37]. These neuropeptides are released from the pancreas on electrical vagal activation $[35,36,38]$. Furthermore, these neuropeptides stimulate both insulin and glucagon secretion in vivo as well as in vitro [35-44]. Both from a morphological and functional point of view, they are therefore candidates for contributors to islet hormone secretion induced by vagal nerve activation.

Vasoactive intestinal polypeptide and PACAP are ubiquitously distributed neuropeptides with close structural resemblances; VIP consists of a 28 amino acid residue whereas PACAP exists in two forms consisting of 27 and 38 amino acids and they show $68 \%$ identity [45]. The close relation between these two neuropeptides is further evident from the finding that the two cloned receptor subtypes with affinity for VIP both also have an affinity for PACAP (VIP and $\mathrm{VIP}_{2}$ receptors, [45]). In addition, there exists a third receptor specific for PACAP (called $\mathrm{PAC}_{1}$ re- 
ceptor, [46]). All these receptors are G-protein coupled receptors of the seven transmembraneous domain type coupled to adenylate cyclase [45]. Insulin producing cells express two of these three receptors (VIP ${ }_{2}$-receptors and $\mathrm{PAC}_{1}$-receptors, [39]), which is consistent with equipotent insulinotropic effects of the two peptides [39]. Both VIP and PACAP stimulate insulin secretion in a glucose-dependent manner accompanied by increased action of adenylate cyclase with increased formation of cAMP [47, 48]. The latter also has other signalling actions in insulin producing tissues such as increasing the cytoplasmic concentration of both $\mathrm{Ca}^{2+}$ and $\mathrm{Na}^{+}$and a distal effect on the exocytosis machinery which might contribute to its potent insulinotropic action [47-49].

Gastrin releasing peptide (GRP) consists of a 27 amino acid residue, is the mammalian homologue of the amphibian peptide bombesin, and is localised to pancreatic nerves, including islet nerve terminals of several species $[9,36]$. Furthermore, GRP is released from the pancreas after vagal nerve activation [36] and stimulates insulin secretion [36, 40-42]. Several different G-protein-coupled receptors showing specific affinity for various bombesin-related peptides have been described, of which one shows a high specific for GRP [50]. In islets, activation by GRP receptors is coupled to PLC and phospholipase D (PLD) $[42,51]$. The islet action of GRP is therefore related to changes in cytoplasmic $\mathrm{Ca}^{2+}$ and through the formation of DAG and activation of PKC. A recent study in insulin producing cells showed that GRP induces a typical pattern of oscillatory actions on cytosolic $\mathrm{Ca}^{2+}$ which is due to both dynamic release of $\mathrm{Ca}^{2+}$ from intracellular stores and to passage of $\mathrm{Ca}^{2+}$ through plasma membrane $\mathrm{Ca}^{2+}$ channels [52]. Importantly, the action of GRP on insulin secretion is not only due to a direct stimulation of the islets because its effect in vivo is inhibited by ganglionic blockade. This together with its localisation to ganglia suggests that GRP is involved in the neural regulation of islet function both as a ganglionic and an islet neurotransmitter [53].

Summary. There are four different neurotransmitters localised to islet parasympathetic nerves (acetylcholine, VIP, PACAP and GRP), all of which are released by activation of the vagus nerve and all of which stimulate insulin and glucagon secretion. They could therefore all contribute to vagally induced stimulation of insulin and glucagon secretion. The four potential parasympathetic neurotransmitters activate islet signalling mechanisms which are partially different. The relative contribution of the four neurotransmitters to the islet hormone responses to vagal nerve activation is not known and needs to be established.

\section{Sympathetic nerves}

Anatomy. The first finding of a potential islet role of the sympathetic nerves was presented in 1940 when it was found that sympathetic nerve activation is accompanied by microscopical changes in the islets [2]. An extensive adrenergic innervation of the islets was later shown by fluorescence microscopy. A rich supply of nerve endings containing amine in close connection with the islet endocrine cells was made visible in several species [6]. Furthermore, islet innervation of adrenergic nerves has also been supported by the localisation in islets of labelled noradrenaline or 5hydroxytryptophan from intact animals that had been given these neurotransmitters in vivo [3]. Moreover, by electron microscopic studies adrenergic nerve terminals in close association with islet endocrine cells have been made visible [54]. Finally, immunocytochemistry has revealed an extensive innervation of islets by staining of islet nerve terminals with enzyme catalysing the formation of noradrenaline, tyrosine hydroxylase [54-56]. The adrenergic nerves innervating the islets are postganglionic with most nerve cell bodies located in the celiac ganglion or in the paravertebral sympathetic ganglia [7, 8]. The preganglionic nerve fibres originate from nerve cell bodies in the hypothalamus and leave the spinal cord at the level of C8 to L3. The fibres then traverse the lesser and greater splanchnic nerves to reach the paravertebral or celiac ganglia [8]. The postganglionic fibres pass from the ganglia within the mixed autonomic nerves which enter the pancreas along its vessels but preganglionic sympathetic nerve fibres can also directly enter the pancreas.

Effects. Electrical activation either of the splanchnic nerves or of the mixed autonomic nerves along a pancreatic artery can be used to examine islet hormone secretion after sympathetic nerve activation. A drawback of the first approach is that other tissues innervated by these nerves are also stimulated allowing indirect influences. The second experimental approach is therefore more specific for activation of the pancreas. For a specific sympathetic activation, this approach requires, however, a concomitant blockade of the joint preganglionic cholinergic nerves. This has usually been accomplished by ganglionic blockade by hexamethonium or muscarinic antagonism by atropine. The result of such stimulation is inhibition of basal and glucose-stimulated insulin secretion as evident both in dogs and calves [57, 58]. Electrical activation of the sympathetic nerves attached to an isolated pancreas preparation also results in inhibition of glucose-stimulated insulin secretion in rats [59], pigs [60] and humans [8]. Electrical activation of the sympathetic nerves further induces a large release of noradrenaline into the pancreatic veins [58]. Because exogenous treatment with noradrenaline inhibits glu- 
cose-stimulated insulin secretion [61], it has been assumed that it is noradrenaline which mediates the inhibitory action of electrical sympathetic activation on glucose-stimulated insulin secretion. This is supported by studies showing that $\alpha$-adrenoceptor blockade by phentolamine counteracts the inhibition of glucose-stimulated insulin secretion by electrical nerve activation $[57,59]$ and that a specific $\alpha_{2}$-adrenoceptor agonist, clonidine, inhibits glucose-stimulated insulin secretion [62]. Noradrenaline could, however, also stimulate insulin secretion by two different actions. Firstly, through its activation of the islet $\beta_{2}$-adrenoceptors which stimulates insulin secretion [63]. Secondly, through a direct action on the alpha cells, probably mediated by both $\alpha_{2}$-adrenoceptors and $\beta_{2^{-}}$ adrenoceptors, which stimulate glucagon secretion $[64,65]$; glucagon might in turn stimulate insulin secretion. Therefore, the net effect of noradrenaline on insulin secretion might depend on the relative abundance or activity of $\alpha$-adrenoceptors compared with $\beta$-adrenoceptors on the beta cells which might differ under different conditions and on the action through glucagon. It should be emphasised that several types of $\alpha_{2}$-adrenoceptors have been expressed in islets and these have been localised to either alpha or beta cells $[66,67]$. Furthermore, $\alpha_{2}$-adrenoceptor activation might increase the local noradrenaline concentration in close vicinity to the beta cells, due to a presynaptic inhibition of noradrenaline uptake [68]. Several direct and indirect mechanisms could, therefore, contribute to the effects of noradrenaline on insulin secretion. In studies using $\alpha$-adrenoceptor blockade as a tool this could be a problem in interpretation because local increase in noradrenaline in combination with postsynaptic $\alpha_{2}$-adrenoceptor blockade could lead to a net stimulation of insulin secretion by $\beta$-adrenoceptor activation. This could offset any inhibition by other mediators. Therefore, approaches using noradrenaline to mimic endogenously released noradrenaline or using a combined $\alpha$ adrenoceptor and $\beta$-adrenoceptor blockade are required to establish the contribution by noradrenaline to the effects of sympathetic nerve stimulation. It has thereby been established that under conditions of stimulated insulin secretion noradrenaline potently inhibits insulin secretion and therefore probably mediates this action of the sympathetic nerves [61, 69]. In contrast, this does not, however, seem to be the case for basal insulin secretion because although sympathetic nerve stimulation clearly inhibits basal insulin secretion, a local infusion of noradrenaline into the pancreatic artery over a wide dose range increased, not reduced, insulin secretion in the dog [58]. Furthermore, combined $\alpha_{2}$-adrenoceptor and $\beta$ adrenoceptor blockade by yohimbine and propranolol could not counteract the inhibition of basal insulin secretion induced by electrical sympathetic activation in dogs, yet the combined adrenergic blockade inhibited the effects of exogenously added noradrenaline [70]. Therefore, noradrenaline does not seem to mediate inhibition by sympathetic nerve stimulation of basal insulin secretion, which therefore might be peptidergic.

The sympathetic nerves also regulate the secretion of the other islet hormones. Thus, glucagon and PP secretions are stimulated by sympathetic nerve activation [57-60, 70, 71] whereas somatostatin secretion is inhibited $[71,72]$. The mechanism of the changes in the secretion of the other islet hormones after sympathetic nerve stimulation is less well characterised. Most studies suggest, however, that these effects are mediated by both $\alpha_{2}$-adrenoceptors and $\beta_{2}$-adrenoceptors as well as by non-adrenergic mechanisms [57-60, 64, 65, 70-72].

Islet signalling of adrenoceptors. Glucose-stimulated insulin secretion is inhibited by noradrenaline activating the $\alpha_{2}$-adrenoceptors or direct activation of these receptors by, for example, clonidine. This inhibition has been shown to be mediated by hyperpolarisation of the beta cells through opening of the ATPregulated $\mathrm{K}^{+}$channels thereby inhibiting the $\mathrm{Ca}^{2+}$ uptake and reducing the cytoplasmic concentration of $\mathrm{Ca}^{2+}$ [73]. Therefore, reduction of the cytoplasmic concentration of $\mathrm{Ca}^{2+}$ is a signalling hallmark of the action of noradrenaline. Activation of islets by $\alpha_{2}$ adrenoceptor has, however, also been shown to inhibit insulin secretion through reduced formation of cyclic AMP [74] and through an inhibitory action on the distal exocytotic machinery [75]. Therefore, several signalling mechanisms seem to underlie the insulinostatic action of noradrenaline. The stimulatory action of $\beta$-adrenoceptor is mediated by increased formation of cAMP in the beta cells [76].

Non-adrenergic mechanisms. The non-adrenergic contribution to the inhibitory action of sympathetic nerves on insulin secretion is possibly mediated by galanin or neuropeptide Y (NPY) or both. These neuropeptides are both localised to the islet sympathetic nerve terminals. This is evident from several different species in which they are co-localised to the adrenergic marker, tyrosine hydroxylase or greatly depleted by 6-hydroxy-dopamine which selectively destroys the sympathetic nerve terminals [56, 77, 78]. Galanin and NPY are also localised to nerve cell bodies in the celiac ganglion, as shown in dogs [56]. Furthermore, galanin is released from the pancreas upon electrical activation of the sympathetic nerves [77] and galanin and NPY both inhibit insulin secretion, in vivo and in vitro [77-81]. The involvement of galanin in inhibition of insulin secretion induced by activation of sympathetic nerves is particularly important in dogs, where galanin is released into the venous effluent of the pancreas during pancreatic sympathetic stimulation in a quantity which is sufficient 
to inhibit insulin secretion [82]. Furthermore, in mice immunoneutralisation of galanin partially prevents a reduction of glucose-stimulated insulin secretion by exercise stress, which is mediated by sympathetic nerve activation [83]. The problem with the concept of a possible contribution by galanin and NPY to sympathetically induced changes in islet hormone secretion is that there seems to be a profound difference between species in the islet localisation and effects of the two neuropeptides. Whereas, for example, dog islets have an extensive galanin innervation, there is only a scanty innervation by galanin nerves in rat or human islets [78]. In mice and pigs, NPY seems to be a constituent not only of sympathetic nerve terminals but also of parasympathetic nerve terminals $[55,84]$. Although a potent inhibition by galanin of insulin secretion has been reported in vivo in dogs [77] no such effect is evident in humans [85]. Inhibition by NPY of glucose-stimulated insulin secretion has been found in studies on rodents [55, 79-81] but no clear effect in dogs [86]. In the pig, galanin and NPY have both been shown to stimulate, not inhibit, insulin secretion [84, 87]. All these findings could be explained, by different experimental conditions, by expression of different receptors under different conditions. Convincing evidence indicating that galanin or NPY contributes to sympathetically induced inhibition of insulin secretion has therefore been presented in only a few species. In future, studies with new approaches on the potential involvement of galanin and NPY in neural regulation of islet function are required. One such approach would be the use of specific receptor antagonists. These receptor antagonists have not been systematically examined after activation of the sympathetic nerves except in a few studies using isolated rat islets or insulin producing cells which have shown that the galanin receptor antagonist galantide [88] or the NPY receptor antagonist (R)-N(2)-(diphenylacetyl)- $N$-[(4-hydroxyphenyl)metheyl]argininamide (BIBP) 3226 [81], prevents galanin or NPY, respectively, from inhibiting insulin secretion. Another approach is the use of mice that have been made deficient of galanin, NPY or their receptors by disruption of the genes. Although galanin-deficient and NPY-deficient mice are available, they have not yet been examined in detail in this respect. Therefore, the net contribution of these neuropeptides to the sympathetic regulation of islet function is not yet established.

Cellular NPY. It should also be mentioned that under some conditions of insulin resistance, such as dexamethasone treatment of rats, NPY is also expressed in islet endocrine cells and that immunoneutralisation of NPY in islets isolated from such rats results in augmentation of insulin secretion [89]. This implies there is a compensatory or adaptive islet mechanism in insulin resistance involving local islet expression of
NPY. This mechanism and function of the neuropeptide would be distinct from its potential role as an islet sympathetic neurotransmitter. A relation between these roles is, however, possible in view of recent findings that chemical sympathectomy by means of 6-hydroxydopamine prevents the expression of NPY in islet endocrine cells after dexamethasone-induced insulin resistance in rats [90]. This implies that the sympathetic nerves regulate the beta-cell expression of NPY. The relevance of this influence in relation to insulin secretion is still to be established.

Islet signalling by galanin and NPY. Both galanin and NPY activate several different receptor subtypes for inducing biological responses. Three galanin receptors (GalR1, GalR2 and GalR3) have been cloned [91] and one of them, GalR1, is expressed in insulinproducing cells [92]. The powerful inhibitory influence of galanin in rodent islets has been shown to be accompanied by a complex signalling mechanism, involving hyperpolarisation and reduction in the cytosolic concentration of $\mathrm{Ca}^{2+}$, although reduced formation of cAMP and inhibition of a direct exocytotic mechanism could also contribute [78]. At least six different NPY receptors have been cloned (Y1, Y2, Y3, Y4, Y5 and Y6 receptors), some of which share an affinity with peptide YY (PYY) and PP [93, 94]. In insulin-producing cells, most evidence favours the Y1 receptor subtype as the receptor mediating islet actions of NPY [81]. The mechanism underlying the inhibition by NPY of glucose-stimulated insulin secretion is not fully established. It seems to involve inhibition of adenylate cyclase with reduced formation of cAMP [81] as well as distal mechanisms in relation to formation of cAMP because insulin secretion stimulated by a cAMP analogue is also inhibited by NPY [80].

Summary. Sympathetic nerves innervate the islets and three neurotransmitter candidates are localised to these nerves and released on their activation (noradrenaline, galanin and NPY). Activation of the sympathetic nerves inhibits basal and glucose-stimulated insulin secretion. Although mediation of this effect by noradrenaline has been established, mediation of the inhibited basal insulin secretion is still not established. Furthermore, the relative contribution of galanin and NPY to islet effects of the sympathetic nerves is also still to be established.

\section{Sensory nerves}

Apart from being innervated by cholinergic and adrenergic nerves, each individual islet is also extensively innervated by a network of sensory nerves with nerve terminals harbouring the sensory neuropeptides, calcitonin gene-related peptide (CGRP) 
and substance $\mathrm{P}$ (SP). The localisation of the 37-amino acid peptide CGRP to islet nerves was first reported in 1983 [95]. Nerves harbouring the 11-amino acid peptide SP, although less numerous than CGRP nerves, have also been found in the pancreatic islets [96]. These sensory islet nerves have been shown to innervate mainly the peripheral portions of the islets $[95,96]$ although occasional nerve fibres are also found in the central part [96]. The fibres are thought to leave the pancreas along the sympathetic fibres within the splanchnic nerves to reach the spinal cord [8]. The role of the islet sensory nerves is far from understood. During recent years results have, however, been presented indicating that the nerves could be involved in the regulation of islet hormone secretion and glucose homeostasis. One line of evidence for such a conclusion is that both CGRP and SP affect islet hormone secretion. Thus, CGRP has been shown to inhibit insulin secretion through a direct action on the islets [97-99] which is accompanied by reduction in cAMP through a pertussis sensitive mechanism [99]. The CGRP receptor subtype responsible for its inhibition of insulin secretion has not yet been established. It should be mentioned that CGRP is related to islet amyloid polypeptide (IAPP). This is a betacell peptide of interest in islet physiology because apart from its potential role in diabetes pathophysiology by forming amyloid fibrils, it has the potential to inhibit insulin secretion [100]. Furthermore, there is a relation in receptor affinity between CGRP and IAPP and also other members of this family of peptides (i.e., calcitonin and adrenomedullin). It has been shown that the so-called "receptor activity-modifying proteins" (RAMP1, RAMP2 and RAMP3), which are single transmembrane proteins modulating the affinity of receptors, transport the calcitonin receptor-like receptor (CRLR) to the cell surface. Depending on which RAMP is transporting the receptor to the surface, affinity for either CGRP, IAPP, calcitonin or adrenomedullin evolves. It has thus been proposed that it is the RAMP1-transported CRLR which results in a receptor form with high affinity for CGRP [101, 102]. Similar regulation has been proposed for the calcitonin receptor [103]. These newly discovered receptor regulatory mechanisms might be of relevance for the function of these peptides [101]. Whether such a mechanism is operative in islet beta cells is still, however, to be established. In contrast to the inhibition by CGRP that has been shown, the influence of SP on insulin secretion is less well characterised. Both inhibitory [104] and stimulatory [105] effects have been reported.

The possible role of the sensory nerves in the regulation of islet function and glucose homeostasis has also been examined with the use of the drug capsaicin as a tool. Treatment of rodents with this agent results in de-afferentation of small unmyelinated C-fibres with a concomitant large reduction in tissue content of CGRP [106]. A substantial reduction of CGRP immunoreactive nerves and a partial reduction in SP immunoreactive nerves has also been shown in islets from mice treated with capsaicin when newborn [96]. This results in an increased glucose-stimulated insulin secretion in the intact mouse [107], suggesting that sensory nerves through their inhibitory neuropeptide CGRP exert a tonic inhibition of insulin secretion. The result in vivo of potentiated glucose-stimulated insulin secretion in mice treated with capsaicin could also indicate that the sensory nerves are involved in a neural reflex activated by glucose, perhaps through activation of glucose sensors in the portal area [108]. Such a reflex could involve efferent adrenergic nerves, judging from studies showing that $\alpha$-adrenoceptor blockade is unable to increase circulating insulin after capsaicin treatment in mice [107]. This would suggest that sensory nerves affect islet function by two mechanisms: by providing a local neural effector function in islets and by being involved in a neural circuit involving peripheral adrenergic nerves.

It has also been shown that glucose elimination is increased in mice after capsaicin treatment [107]. This could be explained as a consequence of the potentiated insulin secretion but also by an increased insulin action because a similar increased elimination was found in streptozotocin diabetic rats [109]. The glucose disposal during recent euglycaemic, hyperinsulinaemic clamp studies was also increased in capsaicin-treated rats [110]. These results imply that the peripheral action of insulin is likewise dependent on intact sensory nerves, which is supported by in vitro studies showing that CGRP reduces the action of insulin [111]. The functional implication and possible relation to Type II diabetes of the potentiation of insulin secretion and improvement of insulin action after capsaicin treatment deserves to be studied in greater detail.

Sensory nerves could also be involved in the regulation of glucagon secretion. Thus, treatment with CGRP stimulates glucagon secretion [98] and the glucagon response to neuroglycopenia induced by the glucose analogue, 2-deoxy-glucose (2-DG), is inhibited after capsaicin treatment [96]. This would suggest that although the sensory nerves inhibit insulin secretion, they stimulate glucagon secretion. Notably, a previous study showed that glucose recovery from insulin-induced hypoglycaemia was impaired after capsaicin treatment [112]. This could imply the regulation of glucagon secretion by the sensory nerves during hypoglycaemia is of physiological importance.

\section{Other nerves}

During recent years, nerve fibres not strictly related to the sympathetic, parasympathetic or sensory nervous system have also been found in the endocrine 
pancreas, e.g. nerve fibres stained for a marker of nitric oxide synthase in islets [113]. This suggests that nitric oxide nerves participate in the regulation of islet function, which is supported by the finding that inhibition of nitric oxide synthase inhibits insulin secretion induced by 2-DG in mice [114]. Furthermore, cholecystokinin is also localised to islet nerves [115]. The CCK nerves might be of importance for insulin secretion because CCK is a potent stimulator of insulin secretion through activation of CCK-A receptors; the insulinotropic activation of CCK is mediated by PLC and PLA 2 [33, 116]. Finally, it has been shown that nerves originating in ganglia in the duodenum might pass directly to the pancreas and innervate pancreatic ganglia, suggesting the existence of a direct entero-pancreatic neural mechanism [117]. The role of these "other" nerves in the regulation of islet function and their relation to the influence of the three main branches should certainly be explored in the future.

\section{Islet autonomic nerves and cephalic phase regulation of islet hormone secretion}

Cephalic phase of insulin secretion. Autonomic and endocrine responses to food ingestion which are triggered by sensory mechanisms and not by the absorbed nutrients are called cephalic phase responses. They consist of three different pathways: first the afferent pathway activated by olfactory, visual, gustatory and oroparyngeal mechanical receptors, second the central integratory mechanism and third the efferent pathway [118]. In rats, a cephalic phase regulation of insulin secretion has been verified by insulin secretion seen during sham feeding $[119,120]$, after food ingestion but before any significant increase in postabsorptive glycaemia is evident [121, 122], and after ingestion of non-metabolisable food [123]. In humans, a cephalic phase regulating insulin secretion was first shown by an increased circulating insulin after imaginary food ingestion under hypnosis [124] and after the sight, smell and expectation of food in healthy subjects [125]. Also combined tease-feeding and ingestion of non-metabolisable sweetener [126] and sham feeding [127] was found to elicit rapid and reliable insulin responses in normal subjects. Moreover, a rapid increase in circulating insulin after oral glucose, before any increase in circulating glucose, has been shown in normal subjects [128]. The cephalic response of insulin secretion is seen in humans within the first 3-4 min, and therefore, when studying this response it is important to sample at an early time after initiation of the stimulus [127].

The cephalic phase stimulation of insulin secretion is activated through stimulation of oral taste receptors and the central integrative circuit has been localised to the ventro-medial hypothalamus and to the

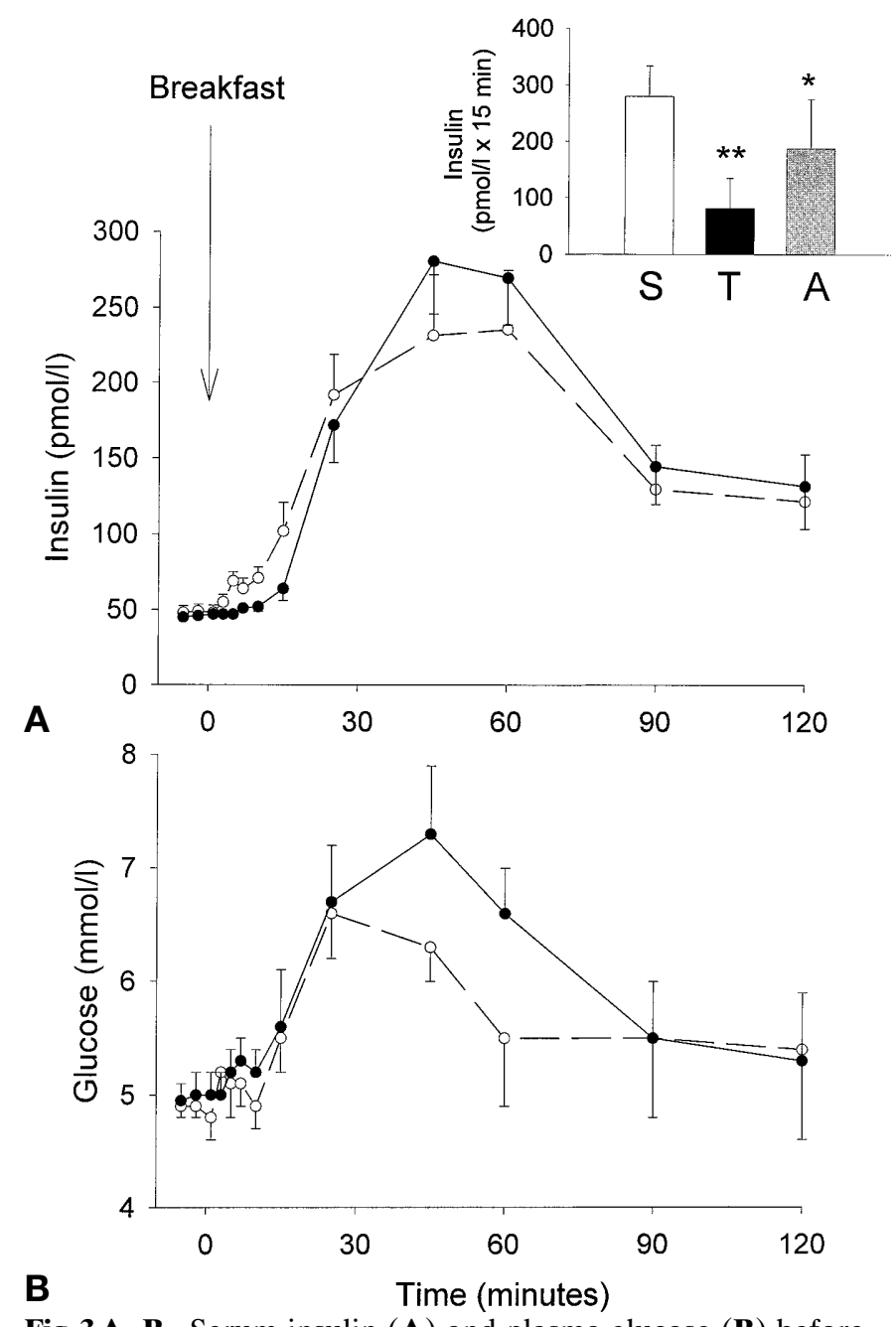

Fig. 3 A, B. Serum insulin (A) and plasma glucose (B) before and at different time points after ingestion of a standard breakfast consisting of two slices of bread, $10 \mathrm{~g}$ margarine, $10 \mathrm{~g}$ marmalade, a slice of $15 \%$ cheese and a cup of black coffee (350 kcal with 28,22 and $50 \%$ of energy coming from protein, fat and carbohydrate, respectively) in six healthy postmenopausal women, 63 years of age. Either saline or the ganglionic antagonist, trimetophane $\left(0.3\right.$ to $\left.0.45 \mathrm{mg} \cdot \mathrm{kg}^{-1} \cdot \mathrm{min}^{-1}\right)$ was infused intravenously from $\min -10$ to min 15 . Insert is the area under the suprabasal insulin as calculated by the trapezoid rule for min 0-15 after start of meal ingestion during infusion of saline $(\mathrm{S})$, trimetophane $(\mathrm{T})$ or during a third experimental condition, when atropine (A) was given as a bolus injection of $0.5 \mathrm{mg}$ at $\mathrm{min}-10$, followed by an intravenous infusion at a rate of $0.05 \mathrm{mg} \cdot \mathrm{kg}^{-1} \cdot \mathrm{min}^{-1}$ until min 15 (results of this experimental series or its saline control not shown as insulin or glucose data). Means \pm SEM are shown. Asterisks indicate the probability level of random difference compared with the control series when saline was infused as determined by a paired non-parametric Wilcoxon signed rank test; $* p<0.05$, $* * p<0.01 . \longrightarrow$ - Saline; $\longrightarrow-$, trimetophane

dorsal motor nucleus of the vagus $[10,119]$. The effector pathway is mediated by the cholinergic neurons within the vagus nerves because it is abolished by vagotomy, by ganglionic blockade and by muscarinic antagonism $[119,121,122]$. Whether the neu- 
ropeptides in the parasympathetic nerves (VIP, PACAP, GRP) contribute to the cephalic phase regulation of islet function is not known. We recently did a series of experiments to examine this by infusing the ganglionic antagonist, trimetophane or the muscarinic antagonist, atropine, into six healthy subjects during ingestion of a meal. In the control experiments, when saline was infused together with the meal intake, there was a clear early insulin response, with insulin concentrations being increased within the first few minutes after meal intake (Fig. 3). When trimetophane was infused, this early insulin response was, however, almost completely abolished and infusion of atropine inhibited the early (15-min) response by approximately $30 \%$ (Fig. 3). This supports the hypothesis that humans also have a cephalic phase regulating insulin secretion and suggests that it is mediated by a ganglionic mechanism and that the postganglionic mechanism is both cholinergic and non-cholinergic. In a recent experimental study in mice a selective PACAP receptor antagonist reduced the early insulin response to a gastric glucose gavage [129]. Although this is not equivalent to the cephalic phase of insulin secretion it suggests involvement of a peptidergic mechanism in the early insulin response to food intake.

Relevance of early insulin response for glucose tolerance. The contribution by the cephalic phase to the entire postprandial insulin secretion is in the range of only $1-3 \%$ of the total insulin secretion after intake of a meal [130]. In spite of this small contribution, the cephalic phase has been suggested to be of considerable functional importance for the rate of glucose excursion and therefore glucose tolerance after meal intake. Thus, rats with transplanted islets, presumed to be denervated, were glucose intolerant after being given administration orally [131]. Treating denervated rats with a minute amount of insulin, to mimic the insulin profile which is seen immediately after oral glucose in normal rats restores glucose tolerance [119]. When glucose is supplied to the gastrointestinal tract but bypassing the oral cavity in the rat (which excludes a cephalic phase of insulin secretion) glucose intolerance is seen [132]. Several studies in humans have also reached similar conclusions. One study for example has shown that the degree of insulin secretion during the cephalic phase correlates negatively to the rise in circulating glucose and positively to the glucose metabolism during a hyperglycaemic clamp [133]. Another study has shown that a simultaneous taste of food in combination with intragastric treatment with glucose increases glucose tolerance [130]. Inhibition of the early prandial insulin response by somatostatin results in deterioration of glucose tolerance [134] and inhibition of the early (15-min) response to a meal by the ganglionic antagonist, trimetophane, is accompanied by increased glucose concentrations at min 45 and 60 (Fig.3). Finally, a brief treatment with insulin during the first $15 \mathrm{~min}$ after food ingestion considerably improves glucose tolerance in subjects with Type II diabetes [135]. Therefore, the cephalic phase regulation of insulin secretion, albeit being marginal in the relation to the entire prandial insulin secretion, seems to be of utmost importance for preserving a normal glucose tolerance after oral glucose. Because the cephalic phase of insulin secretion is mainly neural, these findings indicate that the autonomic nerves have an important role in the preservation of normal glucose tolerance after a meal.

Cephalic phase and glucagon secretion. Apart from a cephalic phase regulation of insulin secretion, a cephalic phase regulation of glucagon secretion has also been shown in rats [136], dogs [137] and humans [130]. The importance of cephalic phase regulation of glucagon secretion is still, however, to be studied in more detail.

\section{Islet autonomic nerves and the synchronisation of islet function}

It is known that individual islet beta cells secrete insulin in a pulsatile manner and that cellular metabolism also shows oscillatory patterns as seen for oxygen consumption, production of ATP and concentrations of cytosolic $\mathrm{Ca}^{2+}[52,138,139]$. This suggests that each cell is a pacemaker for oscillatory regulation of metabolism and secretion. Islet function is also regulated in an oscillatory manner, suggesting islet cells are synchronised so that the islet works as a functional unit. This islet synchronisation has been shown to be due to multiple mechanisms [140]. Insulin secretion from the entire pancreas, not only from individual islets, has also, however, a regular pulsatility [141]. It is therefore likely that synchronisation between islets occurs as well. Recent studies suggest that it is the pancreatic ganglia that governs this synchronisation. Thus, electrophysiological studies have shown that the pancreatic ganglia oscillates [142] and that inhibition of this neuronal activity in the perfused pancreas by nicotinic blockers [143] or by tetrodotoxin [144] abolished the oscillation in insulin secretion. Furthermore, after islet transplantation, the oscillation in insulin secretion disappears but the coordinated pattern of insulin release returns when the graft is reinnervated [145]. The autonomic nerves, perhaps governed by the intrapancreatic ganglia, seem therefore to synchronise the islets. This is probably of great clinical importance because both impaired glucose tolerance and Type II diabetes are characterised by disturbed oscillatory patterns [141]. When the oscillatory pattern is lost, however, in for example diabetes, it is not known whether this is a primary neural dys- 
function or reflects a primary islet dysfunction. One study has shown that when the oscillatory pattern of circulating insulin is lost in the portal vein, liver extraction of insulin is altered, suggesting that the pulsatile pattern of insulin secretion is important for liver insulin extraction and therefore for systemic insulinaemia [146]. Pulsatile treatment with insulin has been shown to more efficiently suppress hepatic glucose production than continuous insulin infusion in subjects with Type I (insulin-dependent) diabetes mellitus, further supporting a physiological role of the pulsatile pattern of insulin secretion [147]. In contrast, in isolated perfused rat livers, insulin seemed equipotent in suppressing the glucose outflow whether given continuously or in a pulsatile fashion [148].

\section{Islet autonomic nerves and homeostatic mechanisms}

Glycopenic stress. During glycopenic stresses such as hypoglycaemia or neuroglycopenia, glucagon secretion is stimulated considerably whereas insulin secretion is inhibited, providing a mechanism for the recovery of circulating glucose through stimulation of hepatic glucose output and inhibition of peripheral glucose uptake [23]. Protection against hypoglycaemia is also achieved by other mechanisms, e.g. release of adrenaline and cortisol as well as a direct stimulation of the release of glucose from the liver [149]. Several studies have shown that the islet nerves are activated during glycopenic stress, thus providing a basis for neural contribution to the changes in islet hormone secretion [23]. Pancreatic polypeptide (marker for parasympathetic nerves) and noradrenaline (marker for sympathetic nerves) were, for example, released into the pancreatic vein during hypoglycaemia in conscious dogs [150]. Neuropeptides localised to the islet autonomic nerve terminals are released during endogenous activation of the autonomic nerves by glycopenic stress (e.g. galanin [151] and VIP [152]), indicating that islet neuropeptidergic fibres are also activated by glycopenic stress. These results imply that local islet nerves are involved in physiological islet adaptation to these metabolic stresses and both the classical neurotransmitters and the neuropeptides mediate the responses. More studies have suggested that this activation of the autonomic nervous system indeed contributes to the islet responses to these metabolic stresses. Ganglionic blockade by hexamethonium, which prevents the autonomic activation during glycopenic stress, considerably reduces for example the glucagon response to hypoglycaemia as well as to neuroglycopenia induced by 2-DG [151, 153]. It was recently also found that in healthy humans ganglionic blockade by trimetophane prevents hypoglycaemia-induced glucagon secretion by approximately $75 \%$, supporting a major role for the autonomic nerves in the mediation of glucagon secre- tion during glycopenic stress in humans [154]. This was confirmed in a case report in which a disease process, that disrupted the activation of the autonomic nerves because of a sarcoid infiltration in the hypothalamus, was associated with an impaired glucagon response to hypoglycaemia [155]. Atropine and adrenergic blockade have also been shown to inhibit glycopenia-induced glucagon secretion, further indicating its neurogenic nature [156]. Therefore, the islet nerves seem important for the mediation of glucagon secretion during glycopenic stress. The relative contribution of parasympathetic compared with sympathetic mechanisms as well as between classsical neurotransmitters and neuropeptides is however, still to be established. This neural mediation of the glucagon response to hypoglycaemia seems to have great importance for glucose counterregulation, as is evident from the human study in which the impaired glucagon response during ganglionic blockade correlated to the amount of glucose infused to retain the desired hypoglycaemic value [154].

The contribution by the autonomic nerves to the islet response to hypoglycaemia has clinical implications in view of the impaired glucagon response to hypoglycaemia which is often seen in Type I diabetes $[152,157,158]$. Autonomic failure could therefore contribute to this impairment and because such failure could be induced by previous hypoglycaemia [159], avoidance of hypoglycaemia is of importance.

Therefore, although autonomic failure has not been convincingly shown to be a major cause of impaired glucagon response to hypoglycaemia in Type I diabetes, substantial evidence exists that autonomic nerves are of major importance for the glucagon response to glycopenia in healthy humans and in experimental animals.

Exercise stress. Carbohydrates are the predominant fuel during exercise. In early exercise, breakdown of muscle glycogen serves as the main fuel but as exercise continues glucose delivery from the liver becomes more important [160]. Increasing hepatic glucose delivery is achieved by increased glucagon and lowered insulin concentrations [161-163] although direct activation of hepatic glycogenolysis by liver nerves contribute [163]. A model of standardised swimming stress in mice has been developed to explore the mechanism of the changes in islet hormone secretion during exercise. The model includes $2 \mathrm{~min}$ of swimming, which results in a $50 \%$ reduction in glucose-stimulated insulin secretion concomitantly with a $50 \%$ increase in circulating glucagon [164]. These changes are partially prevented by ganglionic blockade, by $\alpha$-adrenoceptor antagonism and by sympathetic denervation by 6-hydroxydopamine. This indicates they are mediated by activation of the sympathetic nerves through adrenergic mechanisms [165, 166]; sympathetic nerve activation inhibits insulin 
and stimulates glucagon secretion (see above). Mice were pretreated with a high-titre galanin antiserum to examine whether the remaining part of the inhibition of glucose-stimulated insulin secretion during swimming stress is mediated by sympathetic neuropeptides. The rationale for the experiment was the hypothesis that if galanin is a functionally important sympathetic neurotransmitter, immunoneutralisation of the peptide would impair the stress-induced inhibition of insulin secretion. This was also the result because the galanin antiserum was found to prevent the inhibition of insulin secretion during the swimming stress [83]. It is likely, therefore, that the sympathetic nerves make a major contribution to the changes in islet hormone secretion during exercise and this is, at least in experimental animals, mediated in part by noradrenaline and in part by galanin, both released from the islet sympathetic nerve terminals. Adrenaline released from the adrenals seems also to contribute to the changes in islet hormone secretion during exercise under these conditions because like 6-hydroxydopamine, adrenalectomy prevents the inhibition of insulin secretion and stimulation of glucagon secretion in mice while swimming [165]. The combined action of the adrenals and the sympathetic nerves could also be explained by a sequential action. Thus it has been shown in swimming rats that adrenaline released from the adrenals stimulates the local release of noradrenaline from the islet nerve terminals through a $\beta_{2}$-adrenoceptor-mediated action [166]. Noradrenaline might therefore be released both by direct sympathetic activation and indirectly by a presynaptic inhibition of re-uptake induced by adrenaline. Adrenaline might inhibit insulin secretion both by a direct islet action and indirectly by stimulating the liberation of noradrenaline from local islet nerve terminals. This is supported by a study in which the inhibitory influence of adrenaline on glucose-stimulated insulin secretion was partially prevented by destruction of local islet nerve terminals by 6 -hydroxydopamine in isolated mouse islets [167]. The relative contribution of the adrenals and that of the local islet nerves to the changes in islet hormone secretion during exercise is difficult to establish. A major contribution by the sympathetic nerves to changes in islet hormone secretion during exercise is also evident in humans because inhibition of insulin secretion occurs in adrenalectomised humans during exercise by ergometer cycling [168].

Hypovolaemic stress. It is known that insulin secretion is inhibited and glucagon secretion is stimulated during hypovolaemia. This facilitates an increase in circulating glucose to raise the plasma osmotic pressure and preserve the blood volume [169]. These effects are instigated by activation of baroreceptors in the carotid sinuses and mediated by the sympathetic nerves, as seen in an experimental study in cats
[169]. The signalling mechanisms that contribute to these responses are, however, still to be studied.

\section{Islet autonomic nerves, insulin resistance, diabetes and obesity}

It has been shown that there is a close relation between the peripheral insulin sensitivity and insulin secretion because subjects with low insulin sensitivity (insulin resistance) are adapted to secrete more insulin [170, 171]. Experimental induction of insulin resistance in humans by dexamethasone results in the same adaptation [172]. Although the signal mediating this adaptation might involve metabolic factors, such as glucose or non-esterified fatty acids, evidence has accumulated that increased cholinergic activation also participates. Thus, it has been shown that hyperinsulinaemia in the insulin resistant $o b / o b$ mice is considerably reduced by atropine [173] and vagotomy [174] and that in the insulin-resistant state insulin secretion is more readily activated by muscarinic receptor stimulation both in mice [175] and humans [176]. A recent study also showed that cholinergic activation by carbachol returned insulin secretion and glucose intolerance to normal in insulin resistant, high-fat fed mice [177]. Although the relevance of these findings to islet adaptation to insulin resistance is still to be explored in humans, the results suggest that a neural circuit is induced by insulin resistance, the efferent pathway of which, through cholinergic mechanisms, stimulates insulin secretion. A challenging hypothesis is that failure of such a neural circuit results in the development of impaired glucose tolerance or Type II diabetes, conditions mainly characterised by impaired islet adaptation to insulin resistance [171]. An experimental study in a model of Type II diabetes in Chinese hamsters indicated this possibility because islet dysfunction was accompanied by reduced islet innervation [178].

Although hyperinsulinaemia in obesity is mainly a consequence of low insulin sensitivity, it can be speculated that it is a primary event in some cases. It has, for example, been suggested that neurally induced insulin secretion, in particular the cephalic phase regulation of insulin secretion, is exaggerated in pre-obese or obese states, which would result in an inappropriate hyperinsulinaemia after each meal. This in turn would initiate development of obesity, as experimentally verified in rats in which those with the highest cephalic-insulin response to saccharin were found to develop the most obesity when provoked with a fattening diet [119]. Similarly, rats in which the ventromedial hypothalamus has been destroyed secrete more insulin but this increase is reduced by vagotomy in conjunction with the development of obesity [179]. Finally, a study in obese Zucker rats has shown that hyperinsulinaemia evolves before the onset of obesi- 
ty [180]. A comparison which was carefully carried out has shown, however, that obese subjects do not have an exaggerated cephalic phase insulin secretion when calculated in per cent of baseline insulin secretion and the net cephalic phase insulin secretion is negatively correlated to body mass index [127]. This does not support a primarily exaggerated cephalic-insulin response in obesity. The increased insulin secretion in the insulin-resistant state in humans (who are, e.g. obese) is therefore probably in most cases secondary to the insulin resistance. Nevertheless, the contribution by a neural (cholinergic) mechanism to this islet adaptation and its consequences for diabetes are still to be studied in more detail.

\section{Conclusions and perspectives}

Because of fast and tremendous technological development in several different fields, we now have a fairly well established view of the autonomic innervation of the individual islets, the net effect of activation of the nerves, the presumed neurotransmitters mediating these effects and the putative receptors and their signalling pathways. Still, the following burning issues need to be solved in terms of the physiology and pathophysiology of the islet nerves:

1. The relative contribution the adrenergic, cholinergic and non-adrenergic, non-cholinergic pathways make to the mechanism by which nerves stimulate the islet

2. The role of the individual neurotransmitters, their release and pattern of effect when liberated alone or together with other neurotransmitters

3 . The potential involvement of the nerves in islet physiology in conditions other than those related to the cephalic phase and the responses to metabolic stress

4. The possible involvement of the nerves in the pathophysiology of glucose intolerance, Type II diabetes and obesity.

Although suggested by studies undertaken so far, this involvement needs to be more firmly established and the possible mechanisms need to be studied. To this end the development of transgenic animal models and the use of antisense techniques might offer new possibilities for use in combination with more conventional techniques. Therefore, although we have a deeper understanding of the islet nerves than only a few years ago, only fragments of the full picture have emerged.

Acknowledgements. The author is grateful to his collaborators, in particular Drs B.E. Dunning, S. Efendic, P.J. Havel, J.J.Holst， J.W.M.Höppener， S. Karlsson， K.D. Kohnert, G. Pacini, A. B. Steffens, J. S. Stern, A. J. W. Scheurink, F. Sund- ler and G. J. Taborsky Jr, and to R. Alm, L. Bengtsson, U. Gustavsson, K. Knutsson, L. Kvist and M. Persson for expert technical assistance throughout the years. The studies have been supported by grants to B. Ahrén from the Swedish Medical Research Council (grant no 6834), Swedish Diabetes Association, Novo Nordisk, Albert Påhlsson, Ernhold Lundström and Crafoord Foundations, Malmö University Hospital and the Faculty of Medicine, Lund University.

\section{References}

1. Langerhans P (1869) Beiträge zur mikroskopischen Anatomie der Bauspeicheldrüse. Inaugeral-Dissertation. Friedrich-Wilhelms-Universität. (translation by Morrison H (1937) Berlin, pp 1-32 as Contributions to the microscopic anatomy of the pancreas. John Hopkins Press, Baltimore), pp 1-39

2. Woods SC, Porte D Jr (1974) Neural control of the endocrine pancreas. Physiol Rev 54: 596-619

3. Esterhuizen AC, Spriggs TLB, Lever JD (1968) Nature of islet-cell innervation in the cat pancreas. Diabetes 17: 33-36

4. Orci L, Perrelet A, Ravazzola M, Malaisse-Lagae F, Renold AE (1973) A specialized membrane junction between nerve endings and B cells in islets of Langerhans. Eur J Clin Invest 3: 443-445

5. Coupland RE (1958) The innervation of the pancreas of the rat, cat and rabbit as revealed by the cholinesterase technique. J Anat 92: 143-149

6. Cegrell L (1968) Adrenergic nerves and monoamine-containing cells in the mammalian endocrine pancreas. Acta Physiol Scand [Suppl] 314: 17-23

7. Ahrén B, Taborsky GJ Jr, Porte D Jr (1986) Neuropeptidergic versus cholinergic and adrenergic regulation of islet hormone secretion. Diabetologia 29: 827-836

8. Brunicardi FC, Shavelle DM, Andersen DK (1995) Neural regulation of the endocrine pancreas. Int J Pancreatol 18: $177-195$

9. Sundler F, Böttcher G (1991) Islet innervation with special reference to neuropeptides. In: Samols E (ed) The Endocrine Pancreas. Raven Press, New York, pp 29-52

10. Berthoud HR, Powley TL (1990) Identification of vagal preganglionics that mediate cephalic phase insulin response. Am J Physiol 258:R523-R530

11. Godfrey DA, Matschinsky FM (1975) Enzymes of the cholinergic system in islets of Langerhans. J Histochem Cytochem 23: 645-651

12. Bloom SR, Edwards AV (1981) Pancreatic endocrine responses to stimulation of the peripheral ends of the vagus nerve in conscious calves. J Physiol (Lond) 315: 31-41

13. Holst JJ, Grønholt R, Schaffalitzky de Muckadell OB, Fahrenkrug J (1981) Nervous control of pancreatic endocrine secretion in pigs. 2. The effect of pharmacological blocking agents on the response to vagal stimulation. Acta Physiol Scand 111: 9-14

14. Ahrén B, Taborsky GJ Jr (1986) The mechanism of vagal nerve stimulation of glucagon and insulin secretion in the dog. Endocrinology 118: 1551-1557

15. Karlsson S, Ahrén B (1998) Insulin and glucagon secretion by ganglionic nicotinic activation in adrenalectomized mice. Eur J Pharmacol 342: 291-295

16. Stagner JI, Samols E (1986) Modulation of insulin secretion by pancreatic ganglionic nicotinic receptors. Diabetes 35: 849-854 
17. Van der Zee EA, Buwalda B, Strubbe JH, Strosberg AD, Luiten PG (1992) Immunocytochemical localization of muscarinic acetylcholine receptors in the rat endocrine pancreas. Cell Tissue Res 269: 99-106

18. Boschero AC, Szpak-Glasman M, Carneiro EM et al. (1995) Oxotremorine-m potentiation of glucose-induced insulin release from rat islets involves M3 muscarinic receptors. Am J Physiol 268:E336-E342

19. Ahrén B, Karlsson S, Lindskog S (1990) Cholinergic regulation of the endocrine pancreas. In: Aquilonius S, Gillberg PG (eds) Progress in Brain Research, Cholinergic Neurotransmission, vol 84. Elsevier, Amsterdam, pp 209-218

20. Ahrén B, Paquette TL, Taborsky GJ Jr (1986) Effect and mechanism of vagal nerve stimulation on somatostatin secretion in dogs. Am J Physiol 250:E212-E217

21. Iversen J (1973) Effect of acetylcholine on the secretion of glucagon and insulin from the isolated, perfused canine pancreas. Diabetes 22: 381-387

22. Karlsson, Ahrén B (1993) Muscarinic receptor subtypes in carbachol-stimulated insulin and glucagon secretion in the mouse. J Auton Pharmacol 13: 439-446

23. Havel PJ, Taborsky GJ Jr (1989) The contribution of the autonomic nervous system to changes of glucagon and insulin secretion during hypoglycemia stress. Endocr Rev 10: $332-350$

24. Jones SV (1993) Muscarinic receptor subtypes: modulation of ion channels. Life Sci 52: 457-464

25. Verspohl EJ, Tacke R, Mutschler E, Lambrecht G (1990) Muscarinic receptor subtype in rat pancreatic islets: binding and functional studies. Eur $\mathbf{J}$ Pharmacol 178: 303-311

26. Henquin JC, Nenquin M (1988) The muscarinic receptor subtype in mouse pancreatic B cells. FEBS Lett 236: 89-92

27. Kelley GG, Zawalich KC, Zawalich WS (1995) Synergistic interaction of glucose and neurohormonal agonists to stimulate islet phosphoinositide hydrolysis. Am J Physiol 269:E575-E582

28. Verspohl EJ, Herrmann K (1996) Involvement of G proteins in the effect of carbachol and cholecystokinin in rat pancreatic islets. Am J Physiol 271:E65-E72

29. Niwa T, Matsukawa Y, Senda T, Nimura Y, Hidaka H, Niki I (1998) Acetylcholine activates intracellular movement of insulin granules in pancreatic beta-cells via inositol triphosphate-dependent mobilization of intracellular $\mathrm{Ca}^{2+}$. Diabetes 47: 1699-1706

30. Weng L, Davies M, Ashcroft SJ (1993) Effects of cholinergic agonists on diacylglycerol and intracellular calcium levels in pancreatic beta-cells. Cell Signal 5: 777-786

31. Persaud SJ, Jones PM, Howell SJ (1991) Activation of protein kinase $\mathrm{C}$ is essential for sustained insulin secretion in response to cholinergic stimulation. Biochim Biophys Acta 1091: 120-122

32. Konrad RJ, Jolly YC, Major CD, Wolf BA (1992) Carbachol stimulation of phospholipase $\mathrm{A}_{2}$ and insulin secretion in pancreatic islets. Biochem J 287: 283-290

33. Simonsson E, Karlsson S, Ahrén B (1998) $\mathrm{Ca}^{2+}$-independent phospholipase $A_{2}$ contributes to the insulinotropic action of cholecystokinin- 8 in rat islets. Dissociation from the mechanism of carbachol. Diabetes 47: 1436-1443

34. Bishop AE, Polak JM, Green IC, Bryant MG, Bloom SR (1980) The location of VIP in the pancreas of man and rat. Diabetologia 18: 73-78

35. Havel PJ, Dunning BE, Verchere CB, Baskin DG, O'Dorisio T, Taborsky GJ Jr (1997) Evidence that vasoactive intestinal polypeptide is a parasympathetic neurotransmit- ter in the endocrine pancreas in the dog. Regul Pept 71: $163-170$

36. Knuhtsen S, Holst JJ, Baldissera FG et al. (1987) Gastrinreleasing peptide in the porcine pancreas. Gastroenterology 92: 1153-1158

37. Fridolf T, Sundler F, Ahrén B (1992) Pituitary adenylate cyclase-activating polypeptide (PACAP): occurrence in rodent pancreas and effects on insulin and glucagon secretion in the mouse. Cell Tissue Res 269: 275-279

38. Tornøe K, Hannibal J, Fahrenkrug J, Holst JJ (1997) PACAP-(1-38) as neurotransmitter in pig pancreas: receptor activation revealed by the antagonist PACAP(6-38). Am J Physiol 273:G436-G446

39. Filipsson K, Sundler F, Hannibal J, Ahrén B (1998) PACAP and PACAP receptors in insulin producing tissues: localization and effects. Regul Pept 74: 167-175

40. Bloom SR, Edwards AV, Ghatei MA (1983) Endocrine responses to exogenous bombesin and gastrin-releasing peptide in conscious calves. J Physiol (Lond) 334: 37-48

41. Wood SM, Jung RT, Webster JS et al. (1983) The effect of the mammalian neuropeptide, gastrin-releasing peptide (GRP), on gastrointestinal and pancreatic hormone secretion in man. Clin Sci (Colch) 65: 365-371

42. Gregersen S, Ahrén B (1996) Studies on the mechanisms by which gastrin releasing peptide stimulates insulin secretion from mouse islets. Pancreas 12: 48-57

43. Yada T, Sakurada M, Ihida K et al. (1994) Pituitary adenylate cyclase-activating polypeptide is an extraordinarily potent intra-pancreatic regulator of insulin secretion from islet $\beta$-cells. J Biol Chem 269: 1290-1293

44. Filipsson K, Tornøe K, Holst J, Ahrén B (1997) Pituitary adenylate cyclase-activating polypeptide stimulates insulin and glucagon secretion in humans. J Clin Endocrinol Metab 82: 3093-3098

45. Arimura A, Shioda S (1995) Pituitary adenylate cyclase activating polypeptide (PACAP) and its receptors: neuroendocrine and endocrine interaction. Front Neuroendocrinol 16: 53-88

46. Harmar AJ, Arimura A, Gozes I et al. (1998) Nomenclature of receptors for vasoactive intestinal peptide and pituitary adenylate cyclase-activating polypeptide. Pharmacol Rev 50: 265-270

47. Straub SG, Sharp GW (1996) A wortmannin-sensitive signal transduction pathway is involved in the stimulation of insulin release by vasoactive intestinal polypeptide and pituitary adenylate cyclase-activating polypeptide. J Biol Chem 271: 1660-1668

48. Klinteberg KA, Karlsson S, Ahrén B (1996) Signaling mechanisms underlying the insulinotropic effect of pituitary adenylate cyclase-activating polypeptide (PACAP) in HIT-T15 cells. Endocrinology 137: 2791-2798

49. Filipsson K, Karlsson S, Ahrén B (1998) Evidence for contribution by increased cytoplasmic $\mathrm{Na}^{+}$to the insulinotropic action of PACAP38 in HIT-T15 cells. J Biol Chem 273: 32602-32607

50. Jian X, Sainz E, Clark WA, Jensen RT, Battey JF, Northup JK (1999) The bombesin receptor subtypes have distinct G protein specificities. J Biol Chem 274: 11573-11581

51. Wahl MA, Landsbeck EA, Ammon HPT, Verspohl EJ (1992) Gastrin-releasing peptide: binding and functional studies in mouse pancreatic islets. Pancreas 7: 345-351

52. Karlsson S, Ahrén B (1999) Cytosolic $\mathrm{Ca}^{2+}$ oscillations by gastrin releasing peptide in single HIT-T15 cells. Peptides 20: 579-587

53. Karlsson S, Sundler F, Ahrén B (1998) Insulin secretion by gastrin-releasing peptide in mice: ganglionic versus direct islet effect. Am J Physiol 274:E124-E129 
54. Ahrén B, Ericson LE, Lundquist I, Lorén I, Sundler F (1981) Adrenergic innervation of pancreatic islets and modulation of insulin secretion by the sympato-adrenal system. Cell Tissue Res 216: 15-30

55. Pettersson M, Ahrén B, Lundquist I, Böttcher G, Sundler F (1987) Neuropeptide Y: Intrapancreatic neuronal localization and effects on insulin secretion in the mouse. Cell Tissue Res 248: 43-48

56. Ahrén B, Böttcher G, Kowalyk S, Dunning BE, Sundler F, Taborsky GJ Jr (1990) Galanin is co-localized with noradrenaline and neuropeptide $\mathrm{Y}$ in dog pancreas and celiac ganglion. Cell Tissue Res 261: 49-58

57. Bloom SR, Edwards AV (1984) Characteristics of the neuroendocrine responses to stimulation of the splanchnic nerves in bursts in the conscious calf. J Physiol (Lond) 346: 533-545

58. Ahrén B, Veith R, Taborsky GJ Jr (1987) Sympathetic nerve stimulation versus pancreatic norepinephrine infusion in the dog: 1. Effects on basal release of insulin and glucagon. Endocrinology 121: 323-331

59. Kurose T, Seino Y, Nishi S et al. (1990) Mechanism of sympathetic neural regulation of insulin, somatostatin, and glucagon. Am J Physiol 258:E220-E227

60. Holst JJ, Grønholt R, Schaffalitzky de Muckadell OB, Fahrenkrug J (1981) Nervous control of pancreatic endocrine secretion in pigs. V. Influence of the sympathetic nervous system on the pancreatic secretion of insulin and glucagon, and on the insulin and glucagon response to vagal stimulation. Acta Physiol Scand 113: 279-283

61. Porte D Jr, Williams RH (1966) Inhibition of insulin release by norepinephrine in man. Science 152: 1248-1250

62. Skoglund G, Lundquist I, Ahrén B (1988) Selective $\alpha_{2}$ adrenoceptor activation by clonidine: effects on ${ }^{45} \mathrm{Ca}^{2+}$ efflux and insulin secretion from isolated rat islets. Acta Physiol Scand 132: 289-296

63. Ahrén B, Lundquist I (1981) Effects of selective and nonselective $\beta$-adrenergic agents on insulin secretion in vivo. Eur J Pharmacol 71: 93-104

64. Chan SL, Perrett CW, Morgan NG (1997) Differential expression of alpha 2-adrenoceptor subtypes in purified rat pancreatic islet A- and B-cells. Cell Signal 9: 71-78

65. Lacey RJ, Berrow NS, Scarpello JH, Morgan NG (1991) Selective stimulation of glucagon secretion by beta 2adrenoceptors in isolated islets of Langerhans of the rat. Br J Pharmacol 103: 1824-1828

66. Schuit PC, Pipeleers DG (1986) Differences in adrenergic recognition by pancreatic $A$ and B cells. Science 232: 875-877

67. Wang SY, Pilkey DT (1994) Identification in islets of Langerhans of a new rat alpha 2 -adrenergic receptor. Diabetes 43: 127-136

68. Westfall TC (1984) Evidence that noradrenergic transmitter release is regulated by presynaptic receptors. Fed Proc 43: $1352-1357$

69. Ahrén B, Taborsky GJ Jr (1988) Effects of pancreatic noradrenaline infusion on basal and stimulated islet hormone secretion in the dog. Acta Physiol Scand 132: $143-150$

70. Dunning BE, Ahrén B, Veith RC, Taborsky GJ Jr (1988) Non-adrenergic sympathetic neural influences on basal pancreatic hormone secretion Am J Physiol 255:E785-E790

71. Ahrén B, Veith RC, Paquette TL, Taborsky GJ Jr (1987) Sympathetic nerve stimulation versus pancreatic norepinephrine infusion in the dog: 2. Effects on basal release of somatostatin and pancreatic polypeptide. Endocrinology 121: 332-339

72. Holst JJ, Jensen SL, Knuhtsen S, Nielsen OV (1983) Autonomic nervous control of pancreatic somatostatin secretion. Am J Physiol 245:E542-E548

73. Nilsson T, Arkhammar P, Rorsman P, Berggren PO (1988) Inhibition of glucose-stimulated insulin release by $\alpha_{2}$ adrenoceptor activation is parallelled by both a repolarization and a reduction in cytoplasmic free $\mathrm{Ca}^{2+}$ concentration. J Biol Chem 263: 1855-1860

74. Nakaki T, Nakadate T, Ishii K, Kato R (1981) Postsynaptic $\alpha_{2}$-adrenergic receptors in isolated rat islets of Langerhans: inhibition of insulin release and cyclic $3 ': 5$ '-adenosine monophosphate accumulation. J Pharmacol Exp Ther 216: 607-612

75. Sharp GW (1996) Mechanisms of inhibition of insulin release. Am J Physiol 271:C1781-C1799

76. Kuo WN, Hodgins DS, Kuo JF (1973) Adenylate cyclase in islets of Langerhans: isolation of islets and regulation of adenylate cyclase activity by various hormones and drugs. J Biol Chem 248: 2705-2711

77. Dunning BE, Ahrén B, Veith RC, Böttcher G, Sundler F, Taborsky GJ Jr (1986) Galanin: a novel pancreatic neuropeptide. Am J Physiol 251:E127-E133

78. Ahrén B, Lindskog S (1992) Galanin and the regulation of islet hormone secretion. Int J Pancreatol 11: 147-160

79. Wang ZL, Bennet WM, Wang RM, Ghatei MA, Bloom SR (1994) Evidence of a paracrine role of neuropeptide $\mathrm{Y}$ in the regulation of insulin release from pancreatic islets of normal and dexamethasone treated rats. Endocrinology 135: 200-206

80. Skoglund G, Gross R, Ahrén B, Loubatières-Mariani MM (1993) Different mechanisms are involved in neuropeptide Y-induced pancreatic vasoconstriction and inhibition of insulin secretion. Eur J Pharmacol 236: 69-74

81. Morgan DG, Kulkarni RN, Hurley JD et al. (1998) Inhibition of glucose stimulated insulin secretion by neuropeptide $\mathrm{Y}$ is mediated via the $\mathrm{Y} 1$ receptor and inhibition of adenylyl cyclase in RIN 5AH rat insulinoma cells. Diabetologia 41: 1482-1491

82. Dunning BE, Taborsky GJ Jr (1989) Galanin release during pancreatic nerve stimulation is sufficient to influence islet function. Am J Physiol 256:E191-E198

83. Dunning BE, Karlsson S, Ahrén B (1991) Contribution of galanin to stress-induced impairment of insulin secretion in swimming mice. Acta Physiol Scand 143: 145-152

84. Sheikh SP, Holst JJ, Skak-Nielsen T et al. (1988) Release of NPY in pig pancreas: dual parasympathetic and sympathetic regulation. Am J Physiol 255:G46-G54

85. Ahrén B (1990) Effects of galanin and calcitonin gene-related peptide on insulin and glucagon secretion in man. Acta Endocrinol 123: 591-597

86. Dunning BE, Ahrén B, Böttcher G, Sundler F, Taborsky GJ Jr (1987) The presence and actions of NPY in the canine endocrine pancreas. Regul Pept 18: 253-265

87. Messell T, Harling H, Böttcher G, Johnsen AH, Holst JJ (1990) Galanin in the porcine pancreas. Regul Pept 28: 161-176

88. Lindskog S, Ahrén B, Land T, Langel Ü, Bartfai T (1992) The novel high-affinity antagonist, galantide, blocks the galanin-mediated inhibition of glucose-induced insulin secretion. Eur J Pharmacol 210: 183-188

89. Jamal H, Jones P, Byrne J et al. (1991) Peptide contents of neuropeptide Y, vasoactive intestinal polypeptide, and $\beta$ calcitonin gene-related peptide and their messenger ribonucleic acids after dexamethasone treatment in the isolated rat islets of Langerhans. Endocrinology 129: 3372-3380 
90. Myrsén-Axcrona U, Ahrén B, Sundler F (1999) Modulatory role of adrenergic nerves on dexamethasone-induced islet cell NPY expression in the rat: evidence from chemical sympathectomy. Pancreas 18: 180-188

91. Branchek T, Smith KE, Walker MW (1998) Molecular biology and pharmacology of galanin receptors. Ann NY Acad Sci 21: 94-107

92. Parker EM, Izzarelli DG, Nowak HP et al. (1995) Cloning and characterization of the rat GALR1 galanin receptor from Rin14B insulinoma cells. Brain Res 28: 179-189

93. Balasubramaniam A (1997) Neuropeptide Y family of hormones: receptor subtypes and antagonists. Peptides 18: 445-457

94. Michel MC, Beck Sickinger A, Cox H et al. (1998) International Union of Pharmacology recommendations for the nomenclature of neuropeptide Y, peptide YY, and pancreatic polypeptide receptors. Pharmacol Rev 50: 143-150

95. Rosenfeld MG, Mermod JJ, Amara SG et al. (1983) Production of a novel neuropeptide encoded by the calcitonin gene via tissue-specific RNA processing. Nature 304: 129-135

96. Karlsson S, Sundler F, Ahrén B (1992) Neonatal capsaicin-treatment in mice: effects on pancreatic peptidergic nerves and 2-deoxy-D-glucose-induced insulin and glucagon secretion. J Auton Nerv Syst 39: 51-60

97. Pettersson M, Ahrén B, Böttcher G, Sundler F (1986) Calcitonin gene-related peptide: occurrence in pancreatic islets in the mouse and the rat and inhibition of insulin secretion in the mouse. Endocrinology 119: 865-869

98. Ahrén B, Mårtensson H, Nobin A (1987) Effects of calcitonin gene-related peptide (CGRP) on islet hormone secretion in the pig. Diabetologia 30: 354-359

99. Pettersson M, Ahrén B (1990) Calcitonin gene-related peptide inhibits insulin secretion. Studies on ion fluxes and cyclic AMP in isolated rat islets. Diabetes Res 15: 9-14

100. Mulder H, Ahrén B, Ekblad E et al. (1999) Islet amyloid polypeptide and adrenomedullin. Novel peptide hormones expressed in the gastro-entero-pancreatic region. In: Greeley GH Jr (ed) Gastrointestinal Endocrinology. Humana Press, Totowa, New Jersey, pp 515-549

101. Muff R, Buhlmann N, Fischer JA, Born W (1999) An amylin receptor is revealed following co-transfection of a calcitonin receptor with receptor activity modifying proteins-1 or -2. Endocrinology 140: 2924-2927

102. Christopoulos G, Perry KJ, Morfis M et al. (1999) Multiple amylin receptors arise from receptor activity-modifying protein interaction with the calcitonin receptor gene product. Mol Pharmacol 56: 235-242

103. Zumpe ET, Tilarakartne F, Fraser NJ, Christopoulos G, Foord SM, Sexton PM (2000) Multiple Ramp domains are required for generation of amylin receptor phenotype from the calcitonin receptor gene product. Biochem Biophys Res Commun 267: 368-372

104. Lundquist I, Sundler F, Ahrén B, Alumets J, Håkanson R (1979) Somatostatin, pancreatic polypeptide, substance P, and neurotensin: cellular distribution and effects on stimulated insulin secretion in the mouse. Endocrinology 104: 832-838

105. Hermansen K (1980) Effects of substance P and other peptides on the release of somatostatin, insulin and glucagon in vitro. Endocrinology 107: 256-261

106. Holzer P (1991) Capsaicin: cellular targets, mechanisms of action, and selectivity for thin sensory neurons. Pharmacol Rev 43: 143-201

107. Karlsson S, Scheurink AJW, Steffens AB, Ahrén B (1994) Involvement of capsaicin-sensory nerves in regulation of insulin secretion and glucose tolerance in conscious mice. Am J Physiol 267:R1071-R1077

108. Niijiima A (1982) Glucose-sensitive afferent nerve fibers in the hepatic branch of the vagus nerve in the guineapig. J Physiol 322: 315-323

109. Guillot E, Costa A, Angel I (1996) Involvement of capsaicin-sensitive nerves in the regulation of glucose tolerance in diabetic rats. Life Sci 59: 969-977

110. Koopman SJ, Leighton B, De Fronzo RA (1998) Neonatal de-afferentation of capsaicin-sensitive sensory nerves increases in vivo insulin sensitivity in conscious adult rats. Diabetologia 41: 813-820

111. Leighton B, Foot EA, Cooper GJS, King JM (1989) Calcitonin gene-related peptide-1 (CGRP-1) is a potent regulator of glycogen metabolism in rat skeletal muscle. FEBS Lett 249: 357-361

112. Zhou XF, Jhamadans KH, Livett BG (1990) Capsaicinsensitive nerves are required for glucostasis but not for catecholamine output during hypoglycemia in rats. Am J Physiol 258:E212-E219

113. Ekblad E, Alm P, Sundler F (1994) Distribution, origin, and projections of nitric oxide synthase-containing neurons in gut and pancreas. Neuroscience 63: 233-248

114. Ahrén B, Karlsson S, Scheurink AJW, Steffens AB (1995) Involvement of nitric oxide in neuroglycopenia-induced insulin and glucagon secretion in the mouse. Eur J Pharmacol 280: 27-35

115. Rehfeld JF, Larsson LI, Goltermann NR et al. (1980) Neural regulation of pancreatic hormone secretion by the C-terminal tetrapeptide of CCK. Nature 284: 33-38

116. Karlsson S, Ahrén B (1992) Cholecystokinin and the regulation of insulin secretion. Scand J Gastroenterol 27: 161-165

117. Kirchgessner AL, Gershon MD (1990) Innervation of the pancreas by neurons in the gut. J Neurosci 10: 1626-1642

118. Powley T (1977) The ventromedial hypothalamic syndrome, satiety, and a cephalic phase hypothesis. Psychol Rev 84: 89-126

119. Berthoud HR, Bereiter DA, Trimble ER, Siegel EG, Jeanrenaud B (1981) Cephalic phase, reflex insulin secretion. Neuroanatomical and physiological characterization. Diabetologia 20: 393-401

120. Strubbe JH (1992) Parasympathetic involvement in rapid meal-associated conditioned insulin secretion in the rat. Am J Physiol 263:R615-R618

121. Strubbe JH, Steffens AB (1975) Rapid insulin release after ingestion of a meal in the unanesthetized rat. Am J Physiol 229: 1019-1022

122. Louis-Sylvestre J (1976) Preabsorbtive insulin release and hypoglycemia in rats. Am J Physiol 230: 56-60

123. Berthoud HR, Trimble ER, Siegel EG, Bereiter DA, Jeanrenaud B (1980) Cephalic-phase insulin secretion in normal and pancreatic islet-transplanted rats. Am J Physiol 238:E336-E340

124. Goldfine ID, Abraira C, Gruenwald D, Goldstein MS (1970) Plasma insulin levels during imaginary food ingestion under hypnosis. Proc Soc Exp Biol Med 133: 274-286

125. Parra-Covarrubis A, Rivera-Rodriguez I, Almarez-Ugalde A (1971) Cephalic phase of insulin secretion in obese adolescents. Diabetes 20: 800-802

126. Bruce DG, Storlien LH, Furler SM, Chisholm DJ (1987) Cephalic phase metabolic response in normal weight adults. Metabolism 36: 721-725

127. Teff KL, Mattes RD, Engelman K, Mattern J (1993) Cephalic-phase insulin in obese and normal-weight men: relation to postprandial insulin. Metabolism 42: 1600-1608 
128. Osuna JI, Poages I, Motino MA, Rodriguez E, Osorio C (1986) Cephalic phase of insulin secretion in obese women. Horm Metab Res 18: 473-475

129. Filipsson K, Holst JJ, Ahrén B (1999) PACAP contributes to insulin secretion induced by gastric gavage in mice. Diabetologia 42[Suppl 1]:A40 (Abstract)

130. Teff KL, Engelman K (1996) Oral sensory stimulation improves glucose tolerance in humans: effects on insulin, Cpeptide, and glucagon. Am J Physiol 270:R1371-R1379

131. Trimble ER, Siegel EG, Berthoud HR, Renold AE (1980) Intraportal islet transplantation: functional assessment in conscious unrestrained rats. Endocrinology 106: 791-797

132. Steffens AB (1976) Influence of the oral cavity on insulin release in the rat. Am J Physiol 230: 1411-1415

133. Bruce DF, Chisholm DJ, Storlein LH, Kragen EW (1988) Physiological importance of deficiency in early prandial insulin secretion in non-insulin dependent diabetics. Diabetes 37: 736-744

134. Calles-Escandon J, Robbins DC (1987) Loss of early phase of insulin release in humans impairs glucose tolerance and blunts thermic effect of glucose. Diabetes 36: $1167-1172$

135. Bruttomesso D, Pianta A, Mari A et al. (1999) Restoration of early rise in plasma insulin levels improves the glucose tolerance of type 2 diabetic patients. Diabetes 48: 99-105

136. De Jong A, Strubbe JH, Steffens AB (1977) Hypothalamic influence on insulin and glucagon release in the rat. Am J Physiol 233:E380-E388

137. Nilsson G, Uvnäs-Wallensten K (1977) Effect of teasing and sham feeding on plasma glucagon concentrations in dogs. Acta Physiol Scand 100: 298-302

138. Hellman B, Gylfe E, Bergsten P et al. (1994) Glucose induces oscillatory $\mathrm{Ca}^{2+}$ signalling and insulin release in human pancreatic beta cells. Diabetologia 37[Suppl 2]:S11-S20

139. Civelek VN, Deeney JT, Fusonie GE, Corkey BE, Tornheim K (1997) Oscillations in oxygen consumption by permeabilized clonal pancreatic beta-cells (HIT) incubated in an oscillatory glycolyzing muscle extract: roles of free $\mathrm{Ca}^{2+}$, substrates, and the ATP/ADP ratio. Diabetes 46: $51-56$

140. Bertuzzi F, Davalli AM, Nano R et al. (1999) Mechanisms of coordination of $\mathrm{Ca}^{2+}$ signals in pancreatic islet cells. Diabetes 48: 1971-1978

141. Polonsky KS, Sturis J, Van Cauter E (1998) Temporal profiles and clinical significance of pulsatile insulin secretion. Horm Res 49: 178-184

142. King BF, Love JA, Szurszewski JH (1989) Intracellular recordings from pancreatic ganglia of the cat. J Physiol (Lond) 419: 379-403

143. Stagner JI, Samols E (1985) Role of intrapancreatic ganglia in regulation of periodic insular secretions. Am J Physiol 248:E522-E530

144. Sundsten T, Ortsäter H, Bergsten P (1998) Inhibition of intrapancreatic ganglia causes sustained and non-oscillatory insulin release from the perfused pancreas. Diabetologia 41[Suppl 1]:A76 (Abstract)

145. Porksen N, Munn S, Ferguson D, O'Brien T, Veldhuis J, Butler P (1994) Coordinate pulsatile insulin secretion by chronic intraportally transplanted islets in the isolated perfused rat liver. J Clin Invest 94: 219-227

146. Porksen N, Munn SR, Steers JL, Veldhuis JD, Butler PC (1996) Effects of somatostatin on pulsatile insulin secretion: elective inhibition of insulin burst mass. Am J Physiol 270:E1043-E1049
147. Bratusch-Marrain PR, Komjati M, Waldhäusl WK (1986) Efficacy of pulsatile versus continuous insulin administration on hepatic glucose production and glucose utilization in type 1 diabetic humans. Diabetes 35: 922-926

148. Komjati M, Astner-Kremsmayr H, Waldhäusl W, Reitgruber W, Breteinecker F, Troch I (1988) Interaction of sympathomimetics and insulin with hepatic glucose production by isolated perfused rat livers: effects of continuous versus pulsatile infusion. Endocrinology 123: 1798-1807

149. Cryer PE (1981) Glucose counterregulation in man. Diabetes 30: 261-264

150. Dunning BE, Scott MF, Neal DW, Cherrington AD (1997) Direct quantification of norepinephrine spillover and hormone output from the pancreas of the conscious dogs. Am J Physiol 272:E746-E755

151. Havel PJ, Mundinger TO, Veith RC, Dunning BE, Taborsky GJ Jr (1992) Corelease of galanin and NE from pancreatic sympathetic nerves during severe hypoglycemia in dogs. Am J Physiol 263:E8-E16

152. Taborsky GJ Jr, Ahrén B, Havel PJ (1998) Autonomic mediation of glucagon secretion during hypoglycemia. Implications for impaired $\alpha$-cell responses in type- 1 diabetes. Diabetes 47: 995-1005

153. Havel PJ, Akpan JO, Curry DL, Stern JS, Gingerich RL, Ahrén B (1993) Autonomic control of pancreatic polypeptide and glucagon secretion during neuroglycopenia and hypoglycemia in mice. Am $\mathrm{J}$ Physiol 265:R246-R254

154. Havel PJ, Ahrén B (1997) Activation of autonomic nerves and the adrenal medulla contributes to increased glucagon secretion during moderate insulin-induced hypoglycemia in women. Diabetes 46: 801-807

155. Fery F, Plat L, Van de Borne P, Cogan E, Mockel J (1999) Impaired counterregulation of glucose in a patient with hypothalamic sarcoidosis. N Engl J Med 340: 852-856

156. Karlsson S, Ahrén B (1991) Contribution of adrenergic nerves and the adrenals to 2-deoxy-D-glucose-induced insulin and glucagon secretion in the mouse. Int $\mathrm{J}$ Pancreatol 10: 207-215

157. Bolli G, De Feo P, Compagnucci P et al. (1983) Abnormal glucose counterregulation in insulin-dependent diabetes mellitus: interaction of anti-insulin antibodies and impaired glucagon and epinephrine secretion. Diabetes 32: 134-141

158. Adamson U, Lins PE, Efendic S, Hamberger B, Wajngot A (1984). Impaired counterregulation of hypoglycemia in a group of insulin-dependent diabetics with recurrent episodes of severe hypoglycemia. Acta Med Scand 216: 215-222

159. Cryer PE (1994) Hypoglycemia: the limiting factor in the management of IDDM. Diabetes 43: 1378-1389

160. Galbo H (1983) Hormonal and Metabolic Adaptation to Exercise. Thieme Verlag, Stuttgart

161. Hirsch IB, Marker JC, Smith LJ et al. (1991) Insulin and glucagon in prevention of hypoglycemia during exercise in humans. Am J Physiol 260:E695-E704

162. Scheurink AWJ, Steffens AB, Benthem L (1988) Central and peripheral adrenoceptors affect glucose, free fatty acids, and insulin in exercising rats. Am $\mathrm{J}$ Physiol 255:R547-R556

163. van Dijk G, Balkan B, Lindfeldt J et al. (1994) Contribution of liver nerves, glucagon, and adrenaline to the glycemic response to exercise in rats. Acta Physiol Scand 150: 305-313

164. Karlsson S, Ahrén B (1990) Insulin and glucagon secretion in swimming mice: effects of autonomic receptor antagonism. Metabolism 39: 724-732 
165. Karlsson S, Ahrén B (1991) Insulin and glucagon secretion in swimming mice. Effects of adrenalectomy and chemical sympathectomy. J Autonom Nerv Syst 32: 183-189

166. Scheurink AWJ, Steffens AB, Bouritius H et al. (1989) Adrenal and sympathetic catecholamines in exercising rats. Am J Physiol 256:R155-R160

167. Karlsson S, Myrsén U, Nieuwenhuizen A, Sundler F, Ahrén B (1997) Presynaptic sympathetic mechanism in the insulinostatic effect of epinephrine in mouse pancreatic islets. Am J Physiol 272:R1371-R1378

168. Järhult J, Holst J (1979) The role of the adrenergic innervation to the pancreatic islets in the control of insulin release during exercise in man. Pflügers Arch 383: 41-45

169. Järhult J, Holst JJ (1978) Reflex adrenergic control of endocrine pancreas evoked by unloading of carotid baroreceptors in cats. Acta Physiol Scand 104: 188-202

170. Bergman RN, Phillips LS, Cobelli C (1981) Physiologic evaluation of factors controlling glucose tolerance in man. J Clin Invest 68: 1456-1467

171. Larsson H, Ahrén B (1996) Failure to adequately adapt reduced insulin sensitivity with increased insulin secretion in women with impaired glucose tolerance. Diabetologia 39: 1099-1107

172. Larsson H, Ahrén B (1999) Insulin resistant subjects lack islet adaptation to acute dexamethasone-induced reduction in insulin sensitivity. Diabetologia 42: 936-943
173. Ahrén B, Lundquist I (1982) Modulation of basal insulin secretion in the obese, hyperglycemic mouse. Metabolism 31: $172-179$

174. Edvell A, Lindström P (1998) Vagotomy in young obese hyperglycemic mice: effects on syndrome development and islet proliferation. Am J Physiol 274:E1034-E1039

175. Ahrén B, Simonsson E, Scheurink AJW, Mulder H, Myrsén U, Sundler F (1997) Dissociated insulinotropic sensitivity to glucose and carbachol in high-fat diet-induced insulin resistance in C57BL/6J mice. Metabolism 46: 97-106

176. DelRio G, Procopio M, Bondi M et al. (1997) Cholinergic enhancement by pyridostigmine increases the insulin response to glucose load in obese patients but not in normal subjects. Int J Obes 21: 1111-1114

177. Ahrén B, Sauerberg P, Thomsen C (1999) Increased insulin secretion and normalisation of glucose tolerance by cholinergic agonism in high-fat fed C57BL/6 J mice. Am J Physiol 277:E93-E102

178. Kohnert KD, Myrsén-Axcrona U, Hehmke B, Klöting I, Sundler F, Ahrén B (1999) Islet neuronal abnormalities associated with impaired insulin secretion in type 2 diabetes in the Chinese hamster. Regul Pept 82: 71-79

179. Jeanrenaud B (1983) Energy fuel and hormonal profile in experimental obesities. Experientia Suppl 44: 57-76

180. Turkenkopf IJ, Johnson PR, Greenwood MRC (1982) Development of pancreatic and plasma insulin in prenatal and suckling Zucker rats. Am J Physiol 242:E220-E225 